\title{
Chapter 34 \\ Factors Influencing Soil Organic Carbon Stock Variations in Italy During the Last Three Decades
}

\author{
M. Fantappiè, G. L'Abate, and E.A.C. Costantini
}

\begin{abstract}
Soils contain about three times the amount of carbon globally available in vegetation, and about twice the amount in the atmosphere. However, soil organic carbon (SOC) has been reduced in many areas, while an increase in atmospheric $\mathrm{CO}_{2}$ has been detected. Recent research works have shown that it is likely that past changes in land use history and land management were the main reasons for the loss of carbon rather than higher temperatures and changes of precipitation resulting from climate change. The primary scope of this work was to estimate soil organic carbon stock (CS) variations in Italy during the last three decades and to relate them to land use changes. The study was also aimed at finding relationships between SOC and factors of pedogenesis, namely pedoclimate, morphology, lithology, and land use, but also at verifying the possible bias on SOC estimation caused by the use of data coming from different sources and laboratories. The soil database of Italy was the main source of information in this study. In the national soil database is stored information for 20,702 georeferentiated and dated observations (soil profiles and minipits) analysed for routine soil parameters. Although the observations were collected from different sources, soil description and analysis were similar, because all the sources made reference to the Soil Taxonomy and WRB classification systems, and soil analyses followed the Italian official methods. Besides horizon description and analysis, soil observations had a set of site information including topography, lithology, and land use. The SOC and bulk density referred to the first $50 \mathrm{~cm}$, thus CS was calculated on the basis of the weighted percentage of SOC, rock fragments volume, and bulk density. A set of geographic attributes were considered to spatialize point information, in particular, DEM $(100 \mathrm{~m})$ and derived SOTER morphological classification, soil regions (reference scale 1:5,000,000) and soil systems lithological groups (reference scale 1:500,000), soil moisture and temperature regimes (raster maps of $1 \mathrm{~km}$ pixel size), land cover (CORINE project, reference scale 1:100,000) at three reference dates: years 1990 and 2000, and an original
\end{abstract}

E.A.C. Costantini $(\bowtie)$

CRA-ABP, Research Centre for Agrobiology and Pedology, 50121 Florence, Italy

e-mail: edoardo.costantini@entecra.it 
update to 2008, obtained with field point observations. The interpolation methodology used a multiple linear regression (MLR). CS was the target variable, while predictive variables were the geographic attributes. Basic statistical analysis was performed first, to find the predictive variables statistically related to CS and to verify the bias caused by different laboratories and surveys. After excluding the biased datasets, the best predictors were selected using a step-wise regression method with Akaike Information Criterion (AIC) as selection and stop criterion. The obtained MLR model made use of the following categorical attributes: (i) decade, (ii) land use, (iii) SOTER morphological class, (iv) soil region, (v) soil temperature regime, (vi) soil moisture regime, (vii) soil system lithology, (viii) soil temperature, (ix) soil aridity index (dry days per year), and, (x) elevation. The interaction between decade and land use variables was also considered in the model. Results indicated that CS was highly correlated with the kind of main type of land use (forest, meadow, arable land), soil moisture and temperature regimes, lithology, as well as morphological classes, and decreased notably in the second decade but slightly increased in the third one, passing form 3.32 Pg, to 2.74 Pg and 2.93 Pg respectively. The bias caused by the variables like "laboratory" and "survey source" could be as large as the $190 \%$.

Keywords Carbon sequestration - Land use change $\cdot$ Factor of pedogenesis . Multiple regression

\subsection{Introduction}

Almost all European countries have ratified the Kyoto Protocol to reduce greenhouse gas (GHG) emissions for the period $2008-2012$ by $6.5 \%$ compared to the 1990 level. Article 3.4 of the protocol indicates soil management as a carbon sequestering strategy to help achieve the emission reduction target (Morari et al., 2006). Sequestering carbon in soil is also beneficial to enhance soil quality: soil organic carbon (SOC) is a major indicator of soil quality and sustainability (Reeves, 1997). The communication of the European Commission "Towards a Thematic Strategy for Soil Protection" (COM 179, 2002; COM 231, 2006) as well as other documents (European Commission, 2008, 2009) points to soil organic matter decrease as one of the main European soil threats.

Both forestry and agricultural soils may be considered as carbon sinks according to the Kyoto Protocol. Agriculture and farming activities do approximately contribute $25 \%$ of the global GHG emissions. In Europe this figure is approximately $10 \%$, excluding emissions due to land use change. Soils with high initial carbon contents are more prone to losses than soils with already low carbon content (Kätterer et al., 2004) assuming "high" SOC content values such as $2-3.4 \%$ and "low" SOC at $<2 \%$. Post and Kwon (2000) estimated that land use changes from arable cropping to grassland resulted in increases in soil carbon of $33 \mathrm{~g} \mathrm{C} \mathrm{m}^{-2}$ year $^{-1}$, although rainfall and the species sown in the new pastures could affect the rate substantially. 
The flux exchange of $\mathrm{CO}_{2}$ between soil and the atmosphere is also so large that it has been estimated at 10 times the flux of carbon dioxide from fossil fuels (Schils et al., 2008). If soil respiration, associated with decomposition and root activity, accounts for two thirds of carbon lost from terrestrial ecosystems (Luo and Zhou, 2006), recent research results (Kirk and Bellamy, 2008; Bouwman, 2001; Marland et al., 2003; West and Post, 2002; West and Marland, 2003; West et al., 2008) have shown that it is likely that past changes in land use history and land management were the dominant reasons for the soil carbon losses. Actually, land use changes, more than increased temperatures and changes of precipitation, resulted in an emission of nearly $2 \mathrm{Pg} \mathrm{C}_{\text {year }}{ }^{-1}$ during the 1990s at the terrestrial scale (Schimel et al., 2001; IPCC, 2001a, b). Costantini et al. (2007) pointed to the poorer organic matter content of Italian soils cultivated with row crops and/or vineyards and olive grooves, in comparison with vegetables, orchards and mixed cultivations, as well as the differences between irrigated crops compared with rainfed cultivations.

There are still many uncertainties and unanswered questions related to the issue of carbon sequestration, such as the relationships with the factors of pedogenesis, the size of sink and its accounting. Statistical analyses of spatially distributed soil samples provide information on changes in soil carbon pools when the measurements are taken at two points in time (Bellamy et al., 2005) or are from a chronosequence (simultaneous measurement at sites with different histories of change behind them, Covington (1981)), but such monitoring activity is absent in most European countries.

The only European region with "true" resampling data is England and Wales, where $40 \%$ of the original sites on a $5 \times 5 \mathrm{~km}$ grid were resampled with an interval of 15-25 years (Bellamy et al., 2005; Bellamy, 2008). These authors reported on soil organic carbon changes in UK and Wales over the period 1978-2003. On the basis of data from the two samplings it was estimated that carbon was lost from soils across England and Wales over the survey period at a mean rate of $0.6 \%$ year $^{-1}$ (relative to the existing soil carbon content in 1978). This estimate was based on the soil carbon content of the top $15 \mathrm{~cm}$ of soil. Converting this to carbon stocks, using a pedotransfer function to estimate bulk density, it was estimated that the soils of England and Wales were losing carbon at the rate of $4.44 \mathrm{Tg} \mathrm{C} \mathrm{year}^{-1}$. However, Smith et al. (2007a, b, c) and Smith (2008), using two soil carbon models, suggested that only 10-20\% of the loss of carbon from soils in England and Wales reported by Bellamy et al. (2005) could be due to climate change. Moreover, recent studies have shown that it is likely that past changes in land use history and land management were the dominant reasons behind carbon losses rather than higher temperatures and changes of precipitation as result of the climate change (Kirk and Bellamy, 2008). Changes in bulk density over time, as well as precision and success rate of actual soil resampling, were acknowledged as more likely factors that dominated the observed changes of soil carbon.

In France, INRA has reported on measured carbon stocks in the top 0-30 cm layer. All data between 1970 and 2000 for different land uses have been pooled and used as an average value for 1990 stock of C (Arrouays et al., 2001, 2002a, b). The carbon stocks in the upper $30 \mathrm{~cm}$ of soils in France should vary from 15 to 
$40 \mathrm{Mg} \mathrm{hm}^{-2}$ in mid France, to $40-50 \mathrm{Mg} \mathrm{hm}^{-2}$ in the richer and more intensive cropping areas in the north and south-west, up to $70 \mathrm{Mg} \mathrm{hm}^{-2}$ in permanent grassland and forest, and $>90 \mathrm{Mg} \mathrm{hm}^{-2}$ in more mountainous areas and wetlands (Arrouays et al., 2001; IFEN, 2007). The highest values are reported in organic soil at $350 \mathrm{Mg}$ $\mathrm{hm}^{-2}$. Soils that are under forest, grassland or pasture always have higher organic carbon stocks than identical soils under arable land. IFEN (2007) reported losses of carbon for soils in some regions and increases of soil carbon in other regions for agricultural soils in France.

The main difficulties with soil carbon monitoring are the large amount of work needed, and consequently high costs, plus the challenge to keep the study methods adequately similar between the monitoring periods. Combining modelling with monitoring can reduce the amount of work and the costs. Soil carbon stock (CS) estimation is also affected by many factors of uncertainty. For instance, depth of ploughing has changed over time. This change is hardly recognized in analysis of trends of the stock of organic C in soils (Schils et al., 2008). Increased temperatures may cause a not-linear carbon loss in combination with extreme drought, as reported in information derived from eddy-covariance studies across Europe in 2003 (Ciais et al., 2005; Reichstein et al., 2006). As bulk density and organic carbon are correlated, and as changes in bulk density may induce changes in the mineral mass of soil collected down to a given depth, it would be needed to have determined bulk density on all sites, with comparable methods, that is rarely the case in most databases.

Moreover, there are the sampling and laboratory biases. Although analysed with the same method, data coming from different laboratories and surveys could vary notably, for various reasons (Giandon, 2000; Ogle et al., 2006; Neff et al., 2002; Lal et al., 2001, 2008; Lal, 2008). In laboratory sources of bias are, for instance, sample handling and pre-treatments (exclusions of living roots, straws, intensity of grinding, etc.), which can be performed differently according to local protocols. In field sampling performed in different parts of the ploughed horizon can notably affect the SOC content, especially when, like in many parts of Italy, ploughing depth reaches $50 \mathrm{~cm}$ and more.

Also the particular time of sampling that could be soon after ploughing, or during crop vegetation, or after the harvest, can influence the bulk of the sample. The reference depth causes another important source of variability. In fact, as most soils are sampled at different depth, according to genetic horizons, the SOC content comes from the weighted averaging of the possible multiple analyzed sub-horizons within the reference depth (Franzluebbers, 2002).

Zdruli et al. (1999) made a first estimation of SOC content for Italy for the depth of 0-30 cm as part of the European Mediterranean SOC estimation at $1 \times 1 \mathrm{~km}$ grid, on the basis of the European Soil Database. Jones et al. (2005) improved the previous estimates and provided a map of percentage SOC for the same depth. Other recent studies (Vitullo, 2006; Pilli et al., 2006) have estimated for instance the CS for forest soils in Italy. Some regional experiences have also been attempted to estimate CS in Emilia Romagna (Guermandi, 2005; Calzolari and Ungaro, 2005; Gardi, 2005), Piedmont (Petrella and Piazzi, 2005; Piazzi, 2006; Stolbovoy et al., 2006), 
Lombardy (Solaro and Brenna, 2005; Cerli et al., 2009), Veneto (Dalla Valle, 2008; Garlato et al., 2009a), Trentino (Garlato et al., 2009b).

The present research work described in this paper was aimed at estimating CS variation in Italy during the last three decades and to relate it to land use changes. The study was also aimed at finding relationships between SOC and the factors of pedogenesis, namely pedoclimate, morphology, lithology, and land use, and at verifying the possible biases on SOC estimation caused by the use of data coming from different survey samplings, times and laboratories.

\subsection{Materials and Methods}

\subsubsection{Methodological Approach}

There are different methodological approaches to estimate soil carbon changes. A first distinction could be made between empirical methods that are based on sampling, and deterministic methods, based on theoretical models, derived from previous studies. A deterministic method is used in the procedures for estimating SOC changes under the Kyoto Protocol, in the International Panel on Climate Change report "Good Practice Guidance for LULUCF" (IPCC, 2003, 2007). Within empirical methods, a further division can be made on the basis of sources: data can come from either specific monitoring activities, or from existing databases. Using monitored data is possible to determine the sample design, to select the soil horizons to be studied, and to ensure the repeatability of sampling and laboratory measurements. In the case of data coming from existing different databases, the above parameters have to be checked before using the data itself.

Whichever the source of the data, they can be interpolated using pure statistical, geostatistical, or mixed approaches. In the statistical approach, data coming from more densely populated "external" datasets are combined with SOC measurements to obtain a statistical model of correlation, which is used to interpolate SOC content (Batjes, 2008; Geissen et al., 2009; Grimm et al., 2008; Hirmas et al., in press; Hoyos and Comerford, 2005; Meersmans et al., 2008; Nyssen et al., 2008). In the statistical approaches external datasets usually refer to the factors of pedogenesis (Jenny, 1941). Remote sensed data can also be added in the regression models (Gomez et al., 2008; Huang et al., 2007; Sankey et al., 2008; Vasques et al., 2008). In the pure geostatistical approach, both the SOC measurement and its localization are considered to obtain a spatial autocorrelation model, which is used for the spatialization. The geostatistical approach can be used to incorporate dense secondary information by means, for instance, of cokriging, multicollocated cokriging, or multicollocated cokriging with varying local mean (Castrignanò et al., 2009).

There are various mixed approaches available, but all of them consider a combination of target data autocorrelation and "external" effects (McBratney et al., 2003; Chai et al., 2008; Grunwald, 2009; Carrè et al., 2007; Simbahan et al., 2006). Hence, mixed approaches can add the geographical position as another factor of 
pedogenesis (SCORPAN model, McBratney et al., 2003). The external datasets can be combined with the spatial autocorrelation of residuals in different ways (e.g. regression kriging and kriging with external drift).

As previously stated, Italy is lacking a monitoring system of SOC, so we made use of the data collected in the national soil database, coming from different surveys and completed in different times. The inherited sample design was then random, with a great inhomogeneous spatial and temporal distribution of samples. Uniformity of soil horizons and repeatability of sampling and laboratory measurements were checked before performing the interpolation analysis.

Data stratification was made ad posteriori, attributing to the measured SOC content the "external" information coming from the different geographic attributes. The resulting table could then be used for basic statistic analysis, as well as to obtain the interpolation map. Therefore, our spatialization model can be considered a pure statistical approach, relating SOC to the soil forming factors.

Soil survey datasets were classed in 3 decades: between 01/01/1979 and 31/12/ 1988; between 01/01/1989 and 31/12/1998; between 01/01/1999 and 31/12/2008. The grouping was aimed at overlapping the times of land use/land cover databases, so that it could reflect the relevance of land use changes in SOC content and CS.

\subsubsection{Data Sources and Data Preparation}

The national soil database (Costantini et al., 2007) was the main source of information for SOC content and bulk density. The national soil database stores information of about 40,068 observations (soil profiles and minipits), 22,517 analyzed for routine and non-routine parameters, and 20,702 observations georeferentiated and dated (date of survey). The 20,702 observations were distributed rather unevenly in the last three decades (1979-1988: 1,676 observations; 1989-1998: 12,063 observations; 1999-2008: 6,963 observations). Although the observations were collected from different sources, soil description and classification were similar, because all the sources made reference to the Soil Survey Manual (USDA, Soil Survey Staff, 1983 and later versions), the Soil Taxonomy (Soil Survey Staff, 1975 and later versions) and the FAO-UNESCO soil classification (1974) and WRB (IUSS-ISRICFAO, 1998). Soil analyses always followed the Italian official methods (MIPAAF, 1992; Sequi and De Nobili, 2000). In particular, SOC content was determined using the Walkley-Black official procedure (1934). In this work, the values were converted to ISO (ISO14235) using the formula proposed by the ECALP project (Ecopedological Map of Alps, 2004-2006) of the European Soil Bureau (Garlato et al., 2009b):

$$
\text { SOC_iso }=0.0763+1.0288 \text { SOC_wb }\left(\mathrm{R}^{2} \text { of } 0.9763\right)
$$

where SOC_iso is the estimation of SOC analysed with ISO (ISO14235) and SOC_wb is the SOC analysed with Walkley-Black. 
We referred SOC and bulk density to the first $50 \mathrm{~cm}$, which comprehend the plough layer, in agricultural soils, and the organic-mineral horizon (A horizon), in forest soils. In the elaboration, SOC of all A horizons with upper boundary within $50 \mathrm{~cm}$ from the mineral soil surface, and of any other type of soil horizon, except of $\mathrm{O}$, Oh, Of, Oi and C, with lower boundary within $50 \mathrm{~cm}$ from the mineral soil surface, were expressed as percentage by weight $\left(\mathrm{dag} \mathrm{kg}^{-1}\right)$. In the case of presence of more than one data of SOC content at the same location, for example in the case of more than one A horizon with upper boundary within $50 \mathrm{~cm}$, one single data was obtained by weighted horizon thickness.

The database had also information about rock fragments content $\left(\mathrm{daL} \mathrm{m} \mathrm{m}^{-3}\right.$ of topsoil) and measured soil bulk density $\left(\mathrm{Mg} \mathrm{m}^{-3}\right)$. However, only $37.5 \%$ of soil observations had measured bulk density, so the dataset was completed using a pedotransfer function, which related bulk density to the amount of clay, silt, OC, and CEC (Pellegrini et al., 2007). The CS was then calculated with the formula:

\section{$\mathrm{CS}=\mathrm{D}^{*}$ SOCcontent ${ }^{*} \mathrm{FEF}^{*} \mathrm{BD}$}

where CS is the carbon stock of topsoil (first $0.5 \mathrm{~m}$ from mineral soil surface) expressed as $\mathrm{Mg} \mathrm{hm}^{-2}$, D is the topsoil depth expressed as $\mathrm{m}$, SOCcontent is the soil organic carbon content expressed as dag $\mathrm{kg}^{-1}$ of fine-earth fraction, FEF is the fine-earth fraction expressed as daL $\mathrm{m}^{-3}, \mathrm{BD}$ is the bulk density expressed as $\mathrm{Mg} \mathrm{m}^{-3}$.

The national soil database is a geographical database, with geographical information such as the soil regions (Righini et al., 2001; Costantini et al., 2007) and soil systems of Italy (Costantini et al., 2003). The map of soil regions is the first informative level for the soil map of Italy and the tool for the soil correlation at the continental level. Soil region is a regionally restricted part of the soil cover characterized by a typical climate and parent material association, with reference scale 1:5,000,000. Soil regions were delineated according to the criteria of the Manual of Procedures Version 1.0 for the Georeferenced Soil Database of Europe (Finke et al., 1998). "Soil systems of Italy" is a national soil database with reference scale at 1:500,000. The geographical database contains information about physiography, morphogenetic processes, river drainage network, lithology, land cover, and land components of the soil systems. A "land component" is a specific combination of morphology, lithology, and land cover of the soil system, with indication of the dominant soil typological units (STU). All soil observations of the national soil database are related to the geography of soil systems by means of the STU to which they belong. Major landforms of the land systems follow the SOTER methodology (FAO, 1995).

In this study, the factor of pedogenesis relief was taken into account considering the SOTER morphological classes, which legend is summarized in Table 34.1. A SOTER morphological raster map of Italy was produced using the Digital Elevation Model of Italy at $100 \mathrm{~m}$. SOTER morphological classes were further grouped in classes as follows: 
Table 34.1 SOTER physiographical classification

\begin{tabular}{lllllll}
\hline $\begin{array}{l}\text { Physiography } \\
\text { and elevation } \\
(\mathrm{m} \text { a.s.1. })\end{array}$ & $\begin{array}{l}\text { Low } \\
\text { hills } \\
(0-200)\end{array}$ & $\begin{array}{l}\text { Medium } \\
\text { hills } \\
(200-300)\end{array}$ & $\begin{array}{l}\text { Medium } \\
\text { hills } \\
(300-400)\end{array}$ & $\begin{array}{l}\text { High } \\
\text { hills } \\
(400-600)\end{array}$ & $\begin{array}{l}\text { Low } \\
\text { mountain } \\
(600-1,500)\end{array}$ & $\begin{array}{l}\text { High } \\
\text { mountain } \\
(1,500-3,000)\end{array}$ \\
\hline Slope (\%) & & & & & & \\
$0-2$ & LP1 & LP1 & LP2 & LP2 & LL1 & LL2 \\
$2-8$ & LF1 & LF2 & LF2 & LF3 & RL1 & RL2 \\
$8-15$ & SH1 & SH2 & SH2 & SH3 & SU1 & SU2 \\
$15-30$ & SH1 & SH2 & SH2 & SH3 & SM1 & SM2 \\
$30-60$ & TH1 & TH2 & TH2 & TH3 & TM1 & TM2 \\
$>60$ & VH1 & VH2 & VH2 & VH3 & VM1 & VM2 \\
\hline
\end{tabular}

(a) LP1 and LF1. Levelled lowlands

(b) LF2, SH1, and SH2. Medium and low rolling hills

(c) LP2, LF3, and SH3. High rolling hills

(d) TH1, TH2, VH1 and VH2. Steep low hills

(e) TH3 and VH3. Steep high hills

(f) LL1, RL1, SU1, SM1, TM1, and VM1. Low mountain

(g) LL2, RL2, SU2, SM2, TM2, and VM2. High mountain

To account for the possible influence of soil parent material in SOC stocks, the lithological attributes of soil systems of Italy were grouped as follows:

(a) Marine sediments, Aeolian deposits, coastal and deltaic deposits, calcarenites and residual soil deposits;

(b) Alluvial and lacustrine deposits, clayey formations;

(c) Effusive and volcanoclastic formations, rudite, sandstone, metamorphic schist, clayey sandstone, marls and marly-pelitic turbidite;

(d) Lagoons and slope deposits;

(e) Calcareous and dolomitic rocks, intrusive and metamorphic non-schist rocks.

The influence of climate was taken into account by classifying the soil moisture and temperature regimes of the observation. The USDA Soil Taxonomy was the reference classification (Soil Survey Staff, 1999). The soil attribute was estimated using an original methodology based on the EPIC software (Costantini et al., 2002, 2005). The dry xeric soil moisture regime, postulated by Van Wambeke (1986), was also considered for a more detailed qualification of the driest pedoclimate in the Mediterranean environment. Maps of soil moisture and temperature regimes (pixel size $1 \mathrm{~km}$ ) were produced by ordinary kriging of soil moisture and temperature regimes of the observations (L'Abate and Costantini, 2004). The raster maps were then transformed in vectors. 
The control of land use on SOC was obtained considering the CORINE Land cover Maps of 1990 and 2000 (Sinanet, 2009), and an update to the year 2008 obtained with field point observations: 9,276 georeferenced point field information on land cover came from the LUCAS project (Land Use Land Cover Annual Survey, European Communities, 2003), and 65,536 from the SIN database (Sistema Informativo Agricolo Nazionale, 2009). A new, specific dataset was produced as revised CORINE land cover layer for the last decade (CORINE, 2009). CORINE polygons were not modified; only land cover attribution was corrected. Land cover classes were further grouped in three great classes: (i) arable land, (ii) forest, (iii) permanent meadow.

Beside the categorical predictive variables listed above, some continuous predictive variables were also considered: (i) the DEM of Italy at $100 \mathrm{~m}$, and derived slope; (ii) the raster maps of soil temperature at $50 \mathrm{~cm}$, and the soil aridity index (dry days per year) (Costantini and L'Abate, 2009; Costantini et al., 2009).

\subsubsection{Data Selection}

The data stored in the national soil database referred to soil samples collected in different surveys, various pedologists, and analysed in different laboratories. To check the presence of possible main biases in the SOC datasets, the values of the 5 datasets storing the largest amount of data (named A, B, C, D, and E) were compared to all the other datasets of the same soil region, analysed during the same decade and in the same land use class. Datasets that were significantly different from all the others were excluded from the successive elaborations. The significance of the differences between the means was tested with the $t$ of Student statistic test.

\subsubsection{Data Elaboration}

The spatialization model considered the SOC content as dependent variable and the geographic attributes, as well as the decade of survey, as predictive variables. Geographic attributes were elevation, slope, soil region, soil system, lithology, soil moisture and temperature regimes, and land use at the date of the survey.

Basic statistic analysis was first performed to investigate the relationship between predictive and dependent variables. An analysis of variance was made to statistically compare the SOC content of samples, classed according to the different attributes, referring to the factors of pedogenesis.

A multiple linear regression analysis was then performed (MLRA) and the best predictors and combination of predictors were selected using a stepwise regression analysis with Akaike Information Criterion (AIC) as selection and stop criterion (Sakamoto and Akaike, 1978). As predictors were both categorical and continuous, values of the continuous were standardized using the formula $\mathrm{z}=(\mathrm{x}-\mu) / \sigma$.

On the basis of the MLRA model obtained, the categorical and continuous variables selected were used to obtain 3 maps of carbon stocks, one for each decade. 
An estimation error analysis was also performed to derive the uncertainty of the prediction. A selection of biased data was then interpolated separately with the same method, to highlight the differences in the maps obtained with the spatial interpolation of biased and unbiased data.

\subsection{Results and Discussion}

\subsubsection{Soil Organic Carbon and Factors of Pedogenesis}

Taking into account the bulk of data, SOC content varies significantly according to soil temperature and moisture regimes (Figs. 34.1 and 34.2). The passage from the Mesic to the Thermic soil temperature regime comports a highly significant decrease of SOC of more than $0.35 \mathrm{dag} \mathrm{kg}^{-1}$, meaning a relative lowering of more than $20 \%$. Similarly, the passage between soil moisture regimes (SMR), from the Udic to the Ustic, Xeric, and dry Xeric, reveals a strong influence of soil humidity on the SOC content. As expected, the soils with a higher SOC content are located in the Udic soil moisture regime, while the passage to Ustic is underlined by a relative decrease of about $25 \%$. A smaller, but always significant decrease marks the difference between the soil with Ustic and Xeric SMR, while the SOC content of soils with dry Xeric regime show the lowest values.

The morphological control on the SOC content is also evident (Fig. 34.3). The data evidence a clear increase sequence from plains to hills and mountains and with

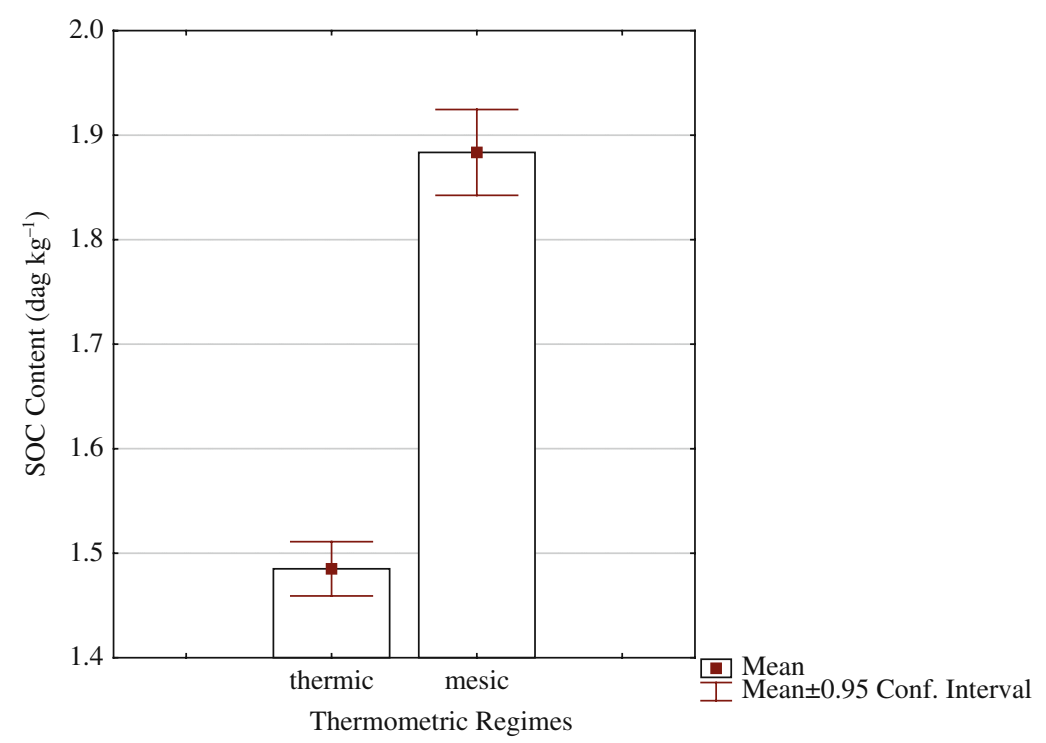

Fig. 34.1 Soil organic carbon content in the main soil temperature regimes of Italy. Differences between means are statistically different $(P<0.01)$ 


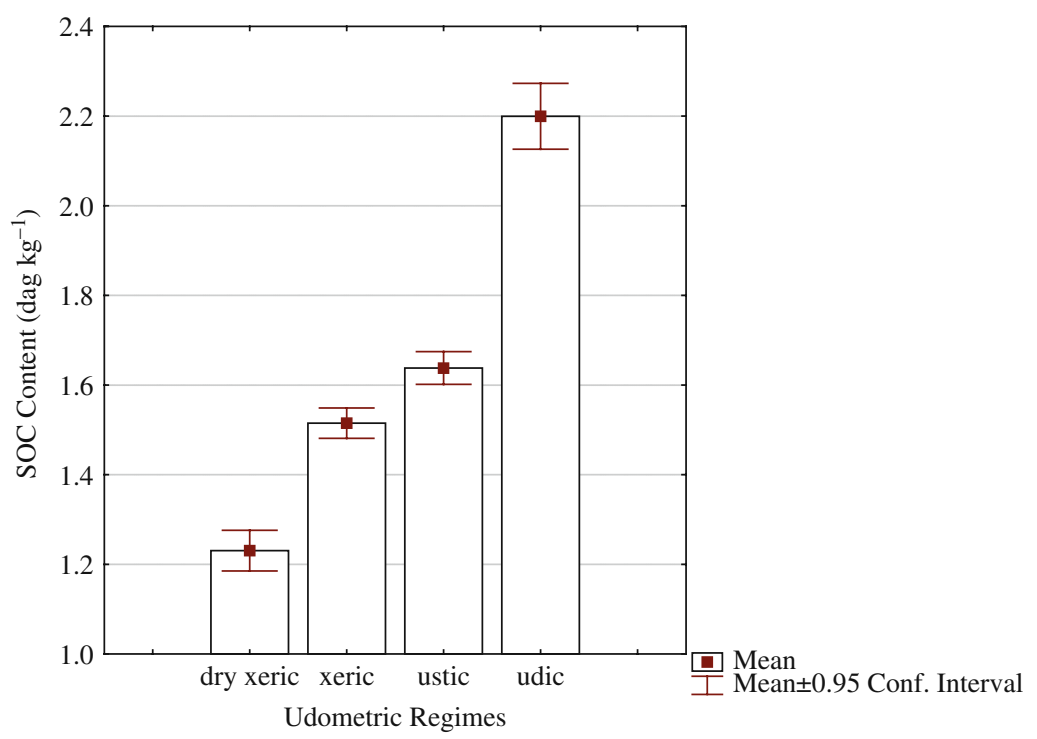

Fig. 34.2 Soil organic carbon content in the main soil moisture regimes of Italy. Differences between means are all statistically different $(P<0.01)$

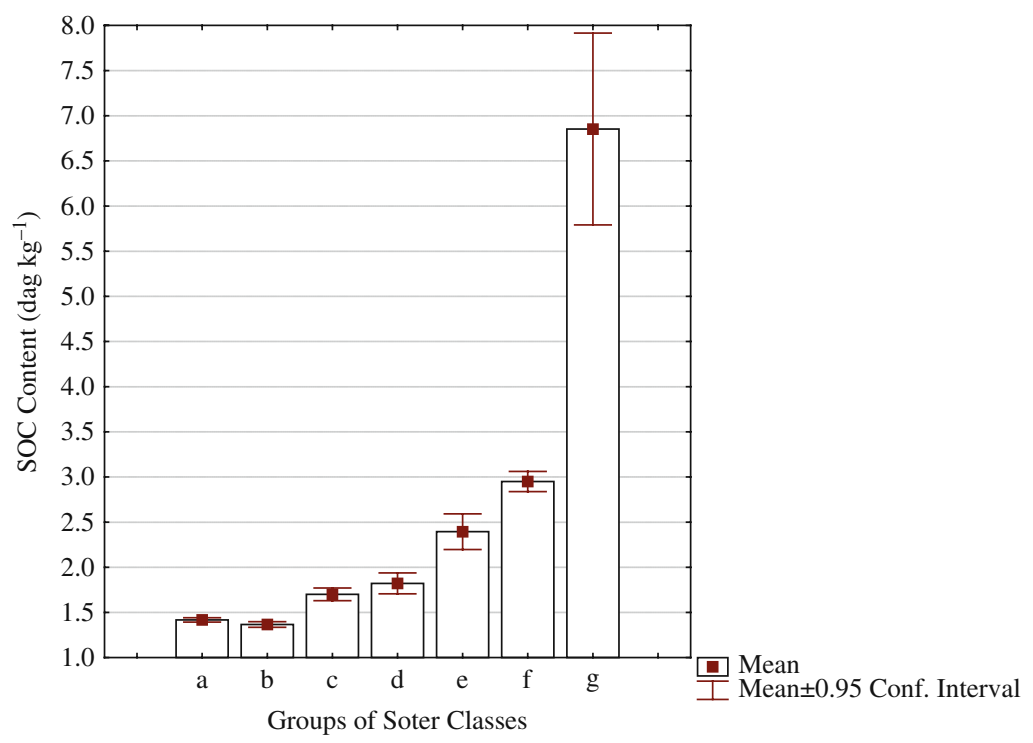

Fig. 34.3 Soil organic carbon content in the groups of SOTER's physiographies. Differences between means are all statistically different $(P<0.01$, or $P<0.05$, between $a$ and $b$ classes $)$, except for the difference between $c$ and $d$ classes 


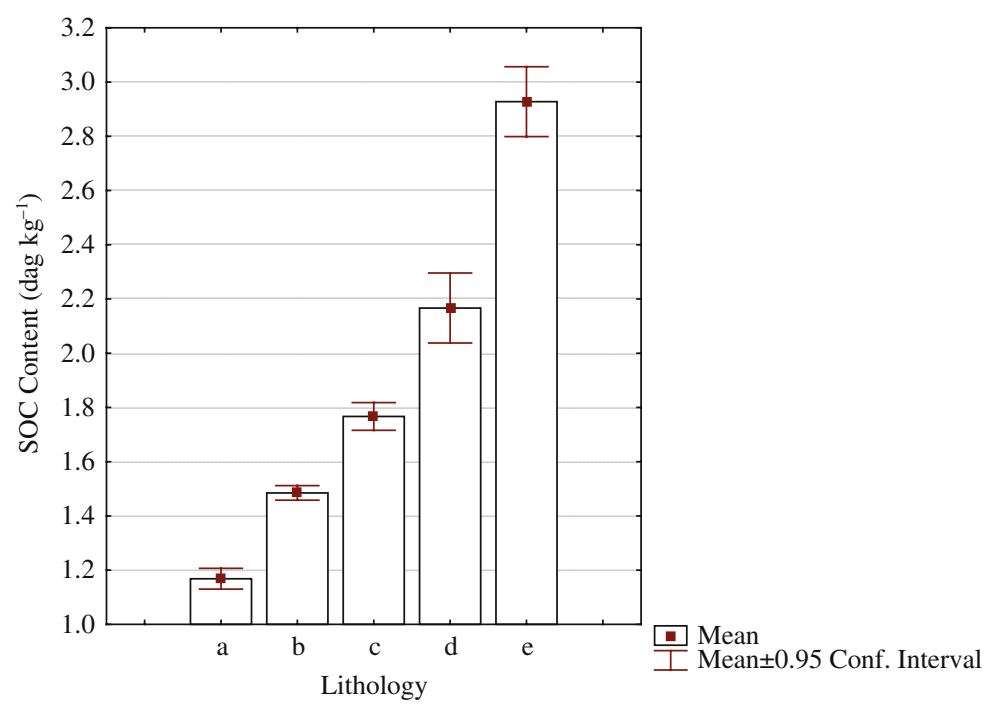

Fig. 34.4 Soil organic carbon content in the main lithological groups of Italy. Differences between means are all statistically different $(P<0.01)$

the increase of steepness. The only exception is the passage from the first to the second class, that is, from levelled lowlands and rolling low hills, where there is a significant decrease. The interpretation is that the effect of morphology on SOC is mediated by the intensity of cultivation of arable lands, which decreases with elevation, where forests and meadows increase, and by climate, as the moister and colder climate enhances soil carbon sequestration. The inverse trend found at the passage from the first and second class can be explained considering that rolling low hills are, as a whole, intensively cultivated in Italy, and the slope of the cultivated fields may trigger soil water erosion.

Lithology influences significantly SOC content, although not as much as morphology (Fig. 34.4). Apart from lagoon and slope deposits, where the high SOC can be related with the presence of peat or organic matter rich deposits, the trend would point to a direct influence of the coherence and hardness of the substratum on SOC. In this case, the lower weathering rate of the rock would favour the organic matter accumulation in the first soil horizons. In addition, carbonate rocks evidence SOC enrichment. It is also reasonable to postulate an interaction with land use, as the harder the rock, the less intensive the agro-system, as well as with climate, in the passage from the lithological classes a and $b$, characterizing plains and hills, and $c$ and e, typical of mountains.

The prominent and straightforward relationship between SOC and land use is evidenced in Fig. 34.5. The transition from arable land to permanent meadow is reflected with increase of SOC content that almost doubles, and triples in forests. However, if the relationship between SOC and land use is clear and simple, the influence of the soil forming factor time is not linear. The data reported in Fig. 34.6 


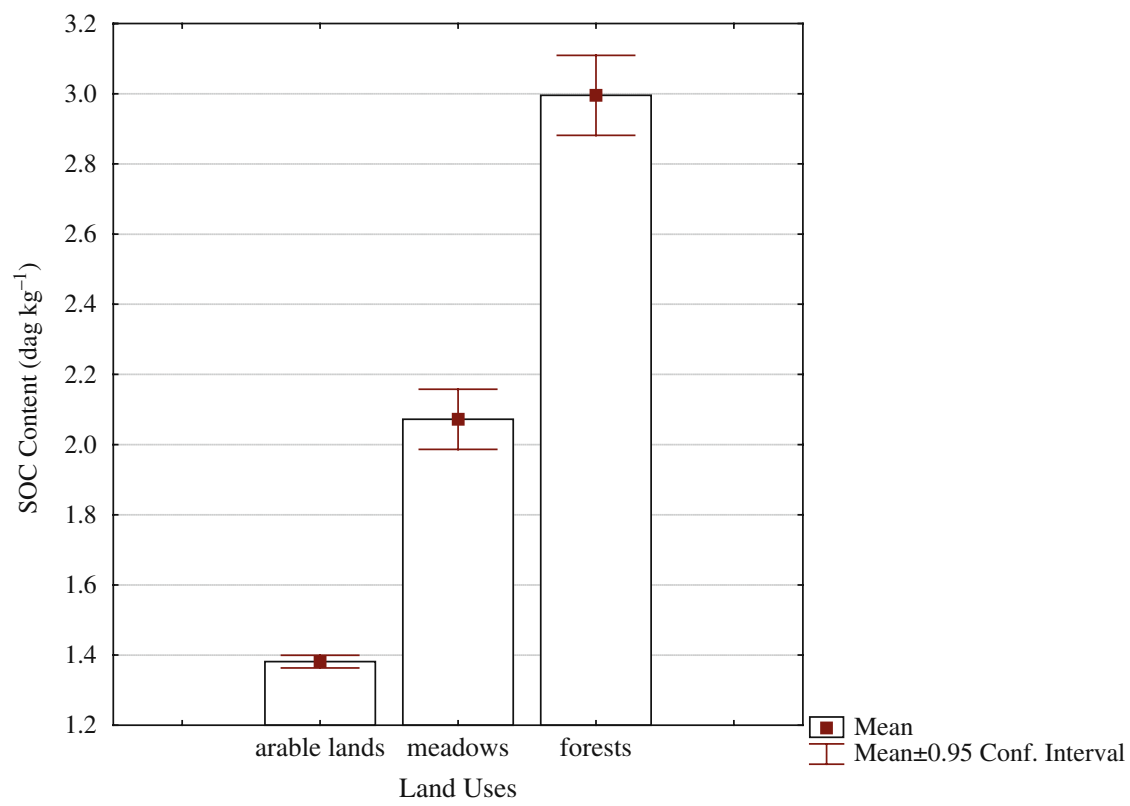

Fig. 34.5 Soil organic carbon content in the main land uses of Italy. Differences between means are all statistically different $(P<0.01)$

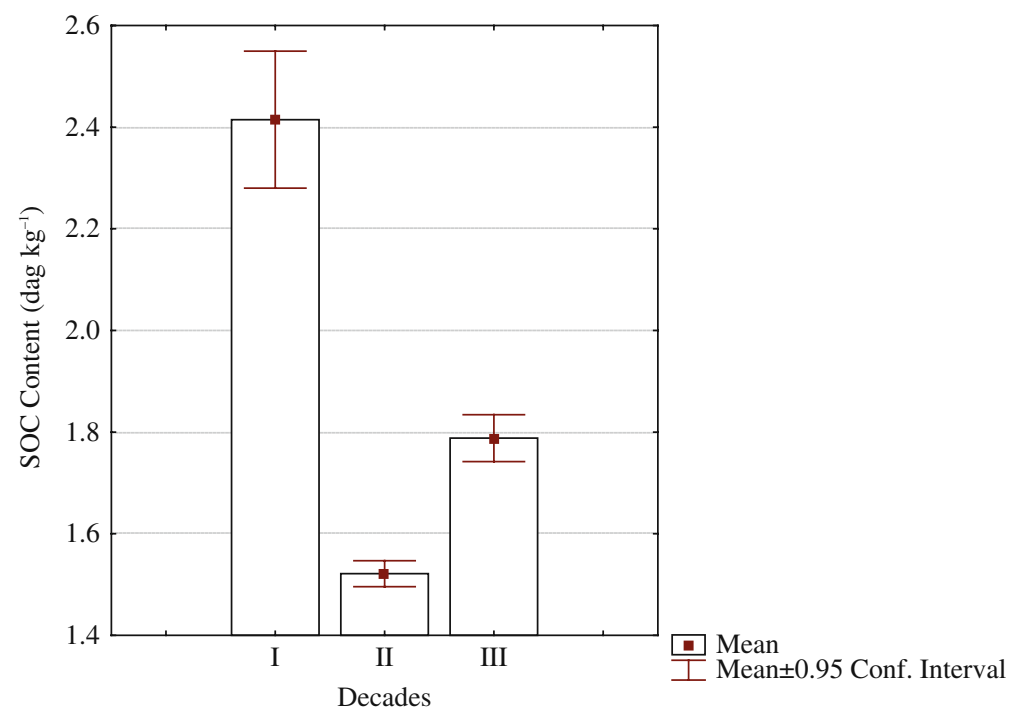

Fig. 34.6 Soil organic carbon content in the three decades considered (I: 1979-1988; II: 1989-1998; III: 1999-2008). Differences between means are all statistically different $(P<0.01)$ 


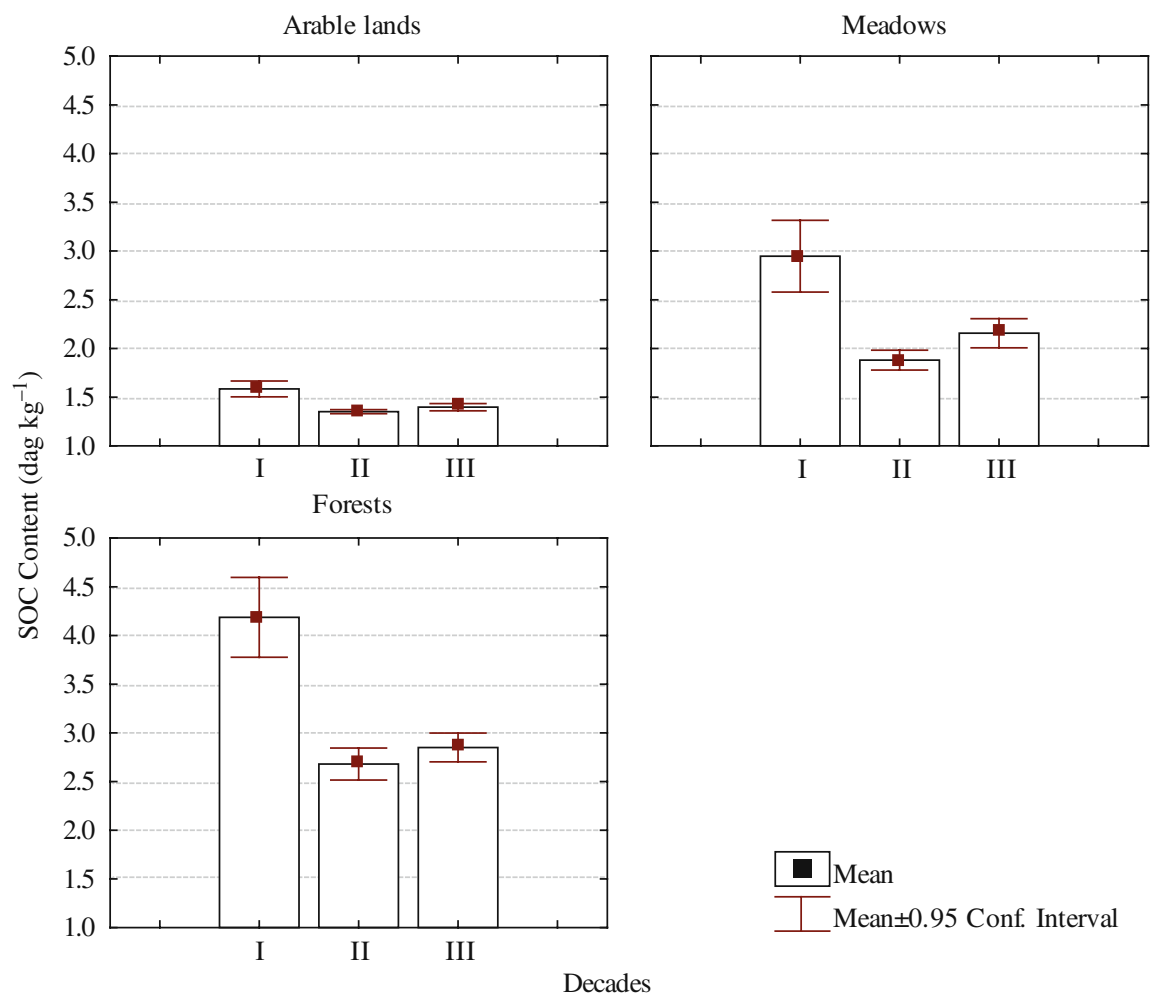

Fig. 34.7 Soil organic carbon content in the three decades considered and land uses. Differences between means are all statistically different $(P<0.01$, or $P<0.05$, between arable lands in decades II and III), except for the difference between forests in decades II and III

indicate a significant lowering of the overall mean in the nineties, with a certain recover in the last decade. The trend is common for the three land use classes considered (Fig. 34.7), although the differences between the second and the third decades become less significant.

\subsubsection{Soil Carbon Stock Variations During the Last Three Decades}

The MLRA model driven by stepwise regression is presented in Table 34.2. Among all the selected factors, the best predictive are land uses, decades, their interactions, SOTER morphological classes, and the continuous variables DEM, soil temperature and dry days. Almost all the soil regions are also highly predictive. Among the lithological groups, the best predictive is the e group (calcareous and dolomitic rocks, intrusive and metamorphic not-schist rocks). 
Table 34.2 Multiple linear regression model adopted for the interpolations of carbon stock $\left(\mathrm{Mg} \mathrm{hm}^{-2}\right)$

\begin{tabular}{|c|c|c|c|c|c|c|}
\hline \multicolumn{2}{|c|}{ Predicting variables } & \multirow{2}{*}{$\begin{array}{c}\begin{array}{l}\text { Estimated } \\
\text { coefficients }\end{array} \\
86.134\end{array}$} & \multirow{2}{*}{$\begin{array}{l}\text { Std. error } \\
4.33\end{array}$} & \multirow{2}{*}{$\begin{array}{l}\mathrm{t} \text { value } \\
19.862\end{array}$} & \multirow{2}{*}{$\begin{array}{l}\operatorname{Pr}(>|\mathrm{t}|) \\
2 \mathrm{e}-16\end{array}$} & \multirow{2}{*}{$\begin{array}{l}\text { Significance } \\
\text { level of } \mathrm{P}\end{array}$} \\
\hline & (Intercept) & & & & & \\
\hline \multicolumn{7}{|l|}{ Categorical } \\
\hline \multirow[t]{2}{*}{ Decade } & II & -11.660 & 2.01 & -5.777 & 7.71e-09 & $* * *$ \\
\hline & III & -0.005 & 2.14 & -0.002 & 0.998081 & \\
\hline \multirow[t]{8}{*}{ Land use } & Forests & 47.881 & 3.63 & 13.169 & $<2 \mathrm{e}-16$ & $* * *$ \\
\hline & Meadows & 14.696 & 4.10 & 3.58 & 0.000344 & $* * *$ \\
\hline & 18 & 20.421 & 2.88 & 7.076 & $1.54 \mathrm{e}-12$ & $* * *$ \\
\hline & 34 & 21.503 & 4.12 & 5.214 & $1.87 \mathrm{e}-07$ & $* * *$ \\
\hline & 35 & 23.141 & 7.48 & 3.092 & 0.001989 & $* *$ \\
\hline & 37 & 16.690 & 4.55 & 3.663 & 0.000250 & *** \\
\hline & 56 & 8.624 & 3.72 & 2.313 & 0.020722 & * \\
\hline & 59 & 8.635 & 3.01 & 2.867 & 0.004142 & ** \\
\hline \multirow{9}{*}{ Soil region } & 60 & -6.236 & 3.39 & -1.836 & 0.066422 & . \\
\hline & 61 & -14.850 & 2.87 & -5.164 & $2.45 \mathrm{e}-07$ & $* * *$ \\
\hline & 62 & -13.850 & 3.01 & -4.589 & $4.49 \mathrm{e}-06$ & $* * *$ \\
\hline & 64 & -3.698 & 3.33 & -1.109 & 0.267256 & \\
\hline & 66 & -5.433 & 4.11 & -1.319 & 0.187204 & \\
\hline & 67 & 24.654 & 7.05 & 3.494 & 0.000476 & $* * *$ \\
\hline & 72 & -2.443 & 5.35 & -0.456 & 0.648393 & \\
\hline & 76 & -11.632 & 4.00 & -2.907 & 0.003656 & $* *$ \\
\hline & 78 & -0.175 & 3.04 & -0.058 & 0.953938 & \\
\hline Soil systems & B & 2.640 & 1.48 & 1.772 & 0.076350 & \\
\hline lithology & $\mathrm{C}$ & -0.645 & 1.55 & -0.414 & 0.678809 & \\
\hline \multirow[t]{2}{*}{ group } & $\mathrm{D}$ & 1.604 & 2.16 & 0.739 & 0.459620 & \\
\hline & $\mathrm{E}$ & 11.357 & 1.99 & 5.689 & $1.30 \mathrm{e}-08$ & $* * *$ \\
\hline \multirow{3}{*}{$\begin{array}{l}\text { Soil moisture } \\
\text { regime }\end{array}$} & Udic & -4.833 & 3.71 & -1.301 & 0.193141 & \\
\hline & Ustic & -5.116 & 2.83 & -1.803 & 0.071382 & . \\
\hline & Xeric & 2.944 & 2.14 & 1.376 & 0.168845 & \\
\hline $\begin{array}{l}\text { Soil } \\
\text { temperature } \\
\text { regime }\end{array}$ & Thermic & 3.198 & 1.49 & 2.133 & 0.032944 & * \\
\hline \multirow{6}{*}{$\begin{array}{l}\text { SOTER } \\
\text { classes } \\
\text { group }\end{array}$} & B & -9.981 & 1.22 & -8.171 & $3.27 \mathrm{e}-16$ & $* * *$ \\
\hline & $\mathrm{C}$ & -15.448 & 2.45 & -6.291 & $3.24 \mathrm{e}-10$ & $* * *$ \\
\hline & $\mathrm{D}$ & -11.734 & 1.86 & -6.28 & $3.47 \mathrm{e}-10$ & $* * *$ \\
\hline & $\mathrm{E}$ & -12.437 & 2.72 & -4.565 & $5.03 \mathrm{e}-06$ & $* * *$ \\
\hline & $\mathrm{F}$ & -4.515 & 3.29 & -1.372 & 0.169998 & \\
\hline & $\mathrm{G}$ & 25.360 & 7.95 & 3.189 & 0.001432 & $* *$ \\
\hline \multicolumn{7}{|l|}{ Continuous } \\
\hline & $\begin{array}{l}\text { Mean annual } \\
\text { soil temp. at } \\
50 \mathrm{~cm}\end{array}$ & 8.077 & 0.864018 & 9.349 & $<2 \mathrm{e}-16$ & $* * *$ \\
\hline & $\begin{array}{l}\text { Soil aridity } \\
\text { index }\end{array}$ & -8.478 & 1.177905 & -7.198 & $6.34 \mathrm{e}-13$ & $* * *$ \\
\hline & Elevation & 11.938 & 1.182095 & 10.099 & $<2 \mathrm{e}-16$ & $* * *$ \\
\hline
\end{tabular}


Table 34.2 (continued)

\begin{tabular}{|c|c|c|c|c|c|c|}
\hline \multicolumn{2}{|c|}{ Predicting variables } & \multirow[t]{2}{*}{$\begin{array}{l}\text { Estimated } \\
\text { coefficients }\end{array}$} & \multirow[t]{2}{*}{ Std. error } & \multirow[t]{2}{*}{$\mathrm{t}$ value } & \multirow[t]{2}{*}{$\operatorname{Pr}(>|t|)$} & \multirow[t]{2}{*}{$\begin{array}{l}\text { Significance } \\
\text { level of P }\end{array}$} \\
\hline Interactions & & & & & & \\
\hline II decade & $\begin{array}{l}\text { Land use forest } \\
\text { Land use } \\
\text { meadow }\end{array}$ & $\begin{array}{r}-16.316 \\
-3.728\end{array}$ & $\begin{array}{l}4.16693 \\
4.398619\end{array}$ & $\begin{array}{l}-3.916 \\
-0.848\end{array}$ & $\begin{array}{l}9.05 \mathrm{e}-05 \\
0.396684\end{array}$ & $* * *$ \\
\hline III decade & $\begin{array}{l}\text { Land use forest } \\
\text { Land use } \\
\text { meadow }\end{array}$ & $\begin{array}{r}-27.937 \\
-5.415\end{array}$ & $\begin{array}{l}4.02584 \\
4.709544\end{array}$ & $\begin{array}{l}-6.939 \\
-1.15\end{array}$ & $\begin{array}{l}4.07 \mathrm{e}-12 \\
0.250171\end{array}$ & $* * *$ \\
\hline
\end{tabular}

*** $<0.0001 ;^{* *}<0.001 ;^{*}<0.05 ; .<0.1$.

The residual standard error is 56.12, with 17,824 degrees of freedom. Multiple R-Squared is 0.1643 and adjusted R-squared 0.1624. F-statistic is 87.62 , with 40 and 17,824 degrees of freedom, P-value is $<2.2 \mathrm{e}-16$. Therefore, although the Fstatistic is very good, the multiple R-squared is quite low. This means that the high variability of the data cannot be well explained by the model, and a large amount of point variation remains unpredicted.

The bulk CS in Italy results $3.32 \mathrm{Pg}$ in the eighties $\left(107 \mathrm{Mg} \mathrm{hm}^{-2}\right), 2.74 \mathrm{Pg}$ in the nineties $\left(88 \mathrm{Mg} \mathrm{hm}^{-2}\right)$, and $2.93 \mathrm{Pg}$ in the years $2000\left(95 \mathrm{Mg} \mathrm{hm}^{-2}\right)$, (Figs. 34.8, 34.9 and 34.10). The distribution of estimation error is presented in Fig. 34.11. The RMSE were of $72.86 \mathrm{Mg} \mathrm{hm}^{-2}$ for the 1 st decade, 44.78 for the 2 nd decade and 65.37 for the 3 rd decade. The variations between decades are reported in Figs. 34.12 and 34.13. The figures of the total budgets are intermediate between the 3.9 Pg postulated by the Natural Resources Conservation Service of the USDA (Schils et al., 2008) and the 2 Pg estimated by the European Soil Bureau (Stolbovoy et al., 2007a, 2007b; Schils et al., 2008).

The CS spatial distribution reveals larger amounts on the Alps, Apennines, and Sardinia, mainly coincident with forests, while the poorer areas are pretty well distributed all over the cultivated plains and hills of the country. It is interesting to note that many hilly lands of central and southern Italy, as well as in Sicily, are territories, which seem to be subjected to both negative and positive changes of CS over time. This could highlight a sensitivity of those soils to SOC modifications.

The trend during the last three decades shows an important decrease in the second decade, which can be probably related to the changes in land use and management, and their consequences on soil bulk density (Horn et al., 1995). Our data actually indicate a change in the distribution of the main land uses over the decades, which influences the calculation of the CS (Table 34.3).

The weight of bulk density on CS estimation in the three decades is highlighted in Fig. 34.14. We noticed that there is an average increase of soil bulk density with time, which is more evident in the third decade for arable lands, and in the second decade for meadows and forest. The outcome confirms what already was observed by many other authors on the enhanced risk of compaction for European soils, due 


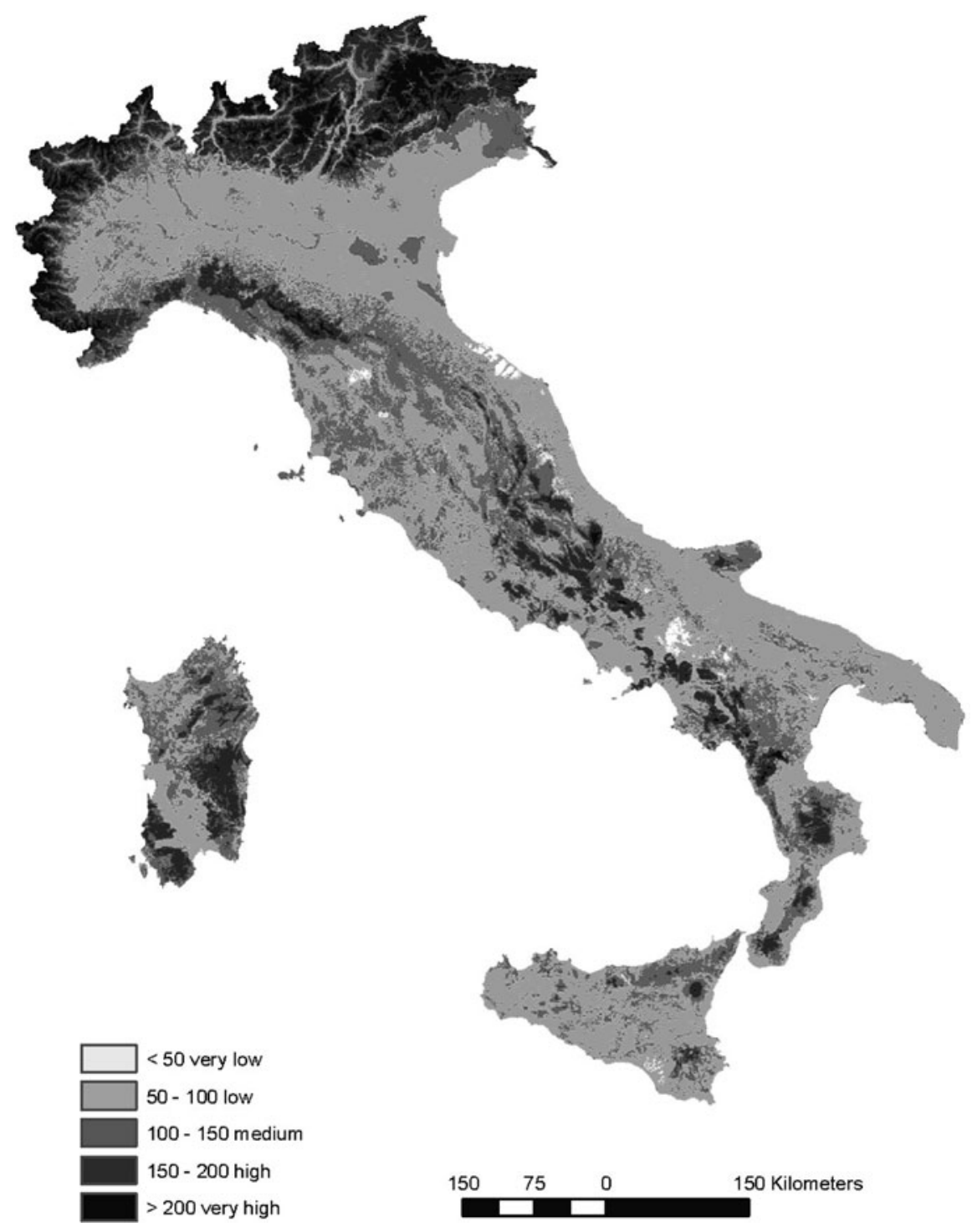

Fig. 34.8 Soil organic carbon stock of Italy in the years 1979-1988

to the steady increase in the diffusion of heavier tractors and machines (SłowińskaJurkiewicz and Domazał, 1991; Alakukku, 1996; Bakken et al., 2009). On the other hand, the increase of soil bulk density in woodlands could be due to the reactivation of timber exploitation activities that occurred in the nineties, after about 20 years of silviculture decline (Vettraino et al., 2009).

It is also possible to observe a positive influence on CS of the European Union directives. As it is well known, during the nineties Italy, likewise many other 


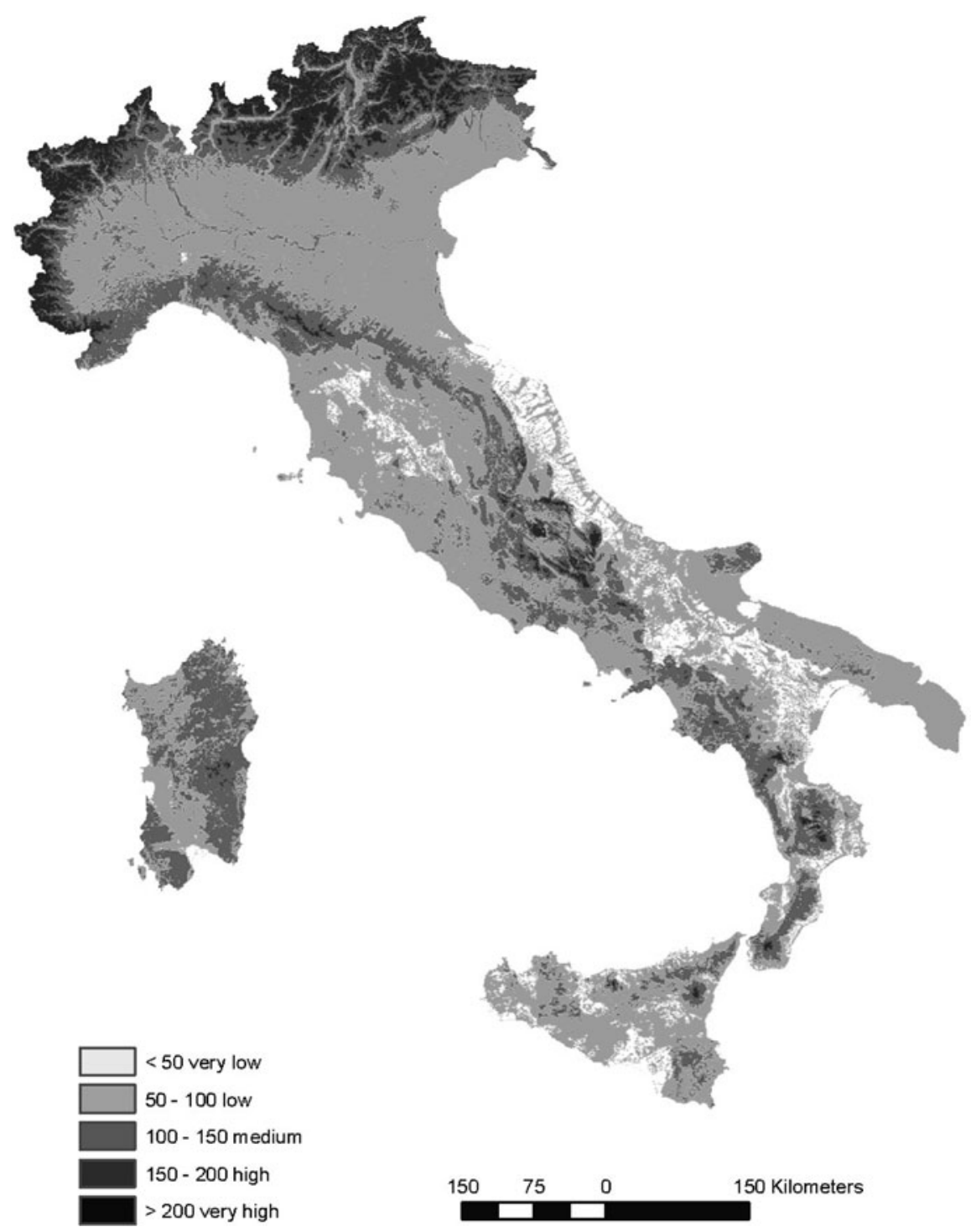

Fig. 34.9 Soil organic carbon stock of Italy in the years 1989-1998

European countries, adopted the so-called "agri-environmental measures" (Reg. CEE 2078/92). The EU applied agri-environmental measures which specifically supported designed farming practices, going beyond the baseline level of "good farming practices" which helped protect the environment and maintain the natural features of the countryside. 


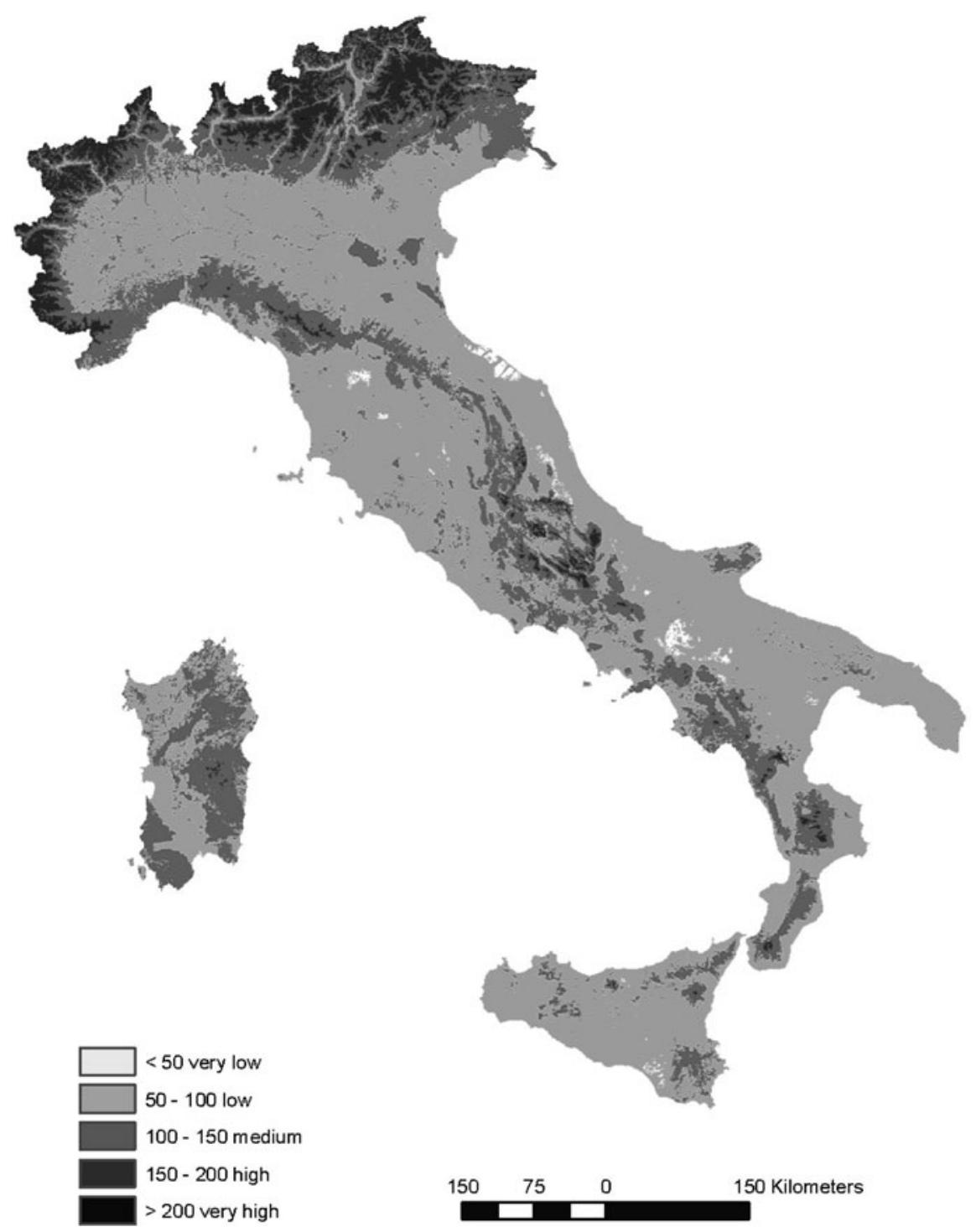

Fig. 34.10 Soil organic carbon stock of Italy in the years 1999-2008

\subsubsection{Survey and Laboratory Biases}

Some 2,937 values of SOC resulted biased in comparison to the others, representing $14.19 \%$ of the total (Table 34.4). They were rather randomly related to different surveys and soil regions, while resulting more frequent in the "arable land" in the second decade. 


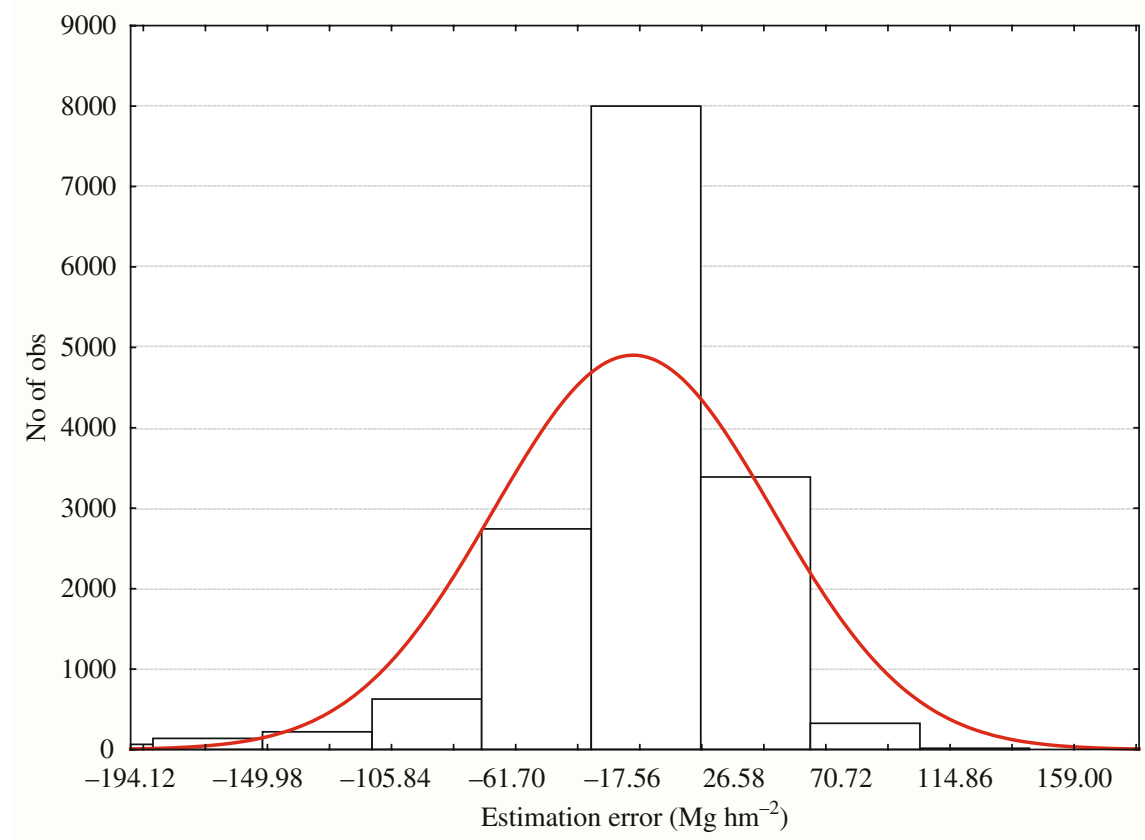

Fig. 34.11 Distribution of estimation error of soil carbon stock in Italy

A comparison between the exemplifying maps of CS made with biased (group $\mathrm{C}$ of the 3rd decade) and unbiased data shows a clear different estimation of CS (Fig. 34.15). The biased map gives an average lower CS estimation of $6.29 \mathrm{Mg}$ $\mathrm{hm}^{-2}$, and a range from $-84 \mathrm{Mg} \mathrm{hm}^{-2}$ to $+75 \mathrm{Mg} \mathrm{hm}^{-2}$.

\subsection{Conclusions}

This study indicates that SOC content of Italian soils is rather low, on average, about $1.8 \mathrm{dag} \mathrm{kg}^{-1}$. The outcome is consistent with what already estimated for the Mediterranean soils by Zdruli et al. (1999), showing that $74 \%$ of soils have less than $2 \%$ organic carbon. On the other hand, the comparison with the data reported for France (Arrouays et al., 2001; IFEN, 2007) indicates a slight larger SOC content of Italian soils. However, it must be considered that the reference depth was 50 in Italy and of $30 \mathrm{~cm}$ in France. Notwithstanding, our results are comparable and indicate an average CS content of $73 \mathrm{Mg} \mathrm{hm}^{-2}$ in arable lands, 95 in meadows, and 116 in forests.

The present research work does not consider the direct influence of climate or climate changes on SOC, but pedoclimate regimes instead. Additionally, soil moisture more than soil temperature regimes, result significantly related to SOC content. Therefore, it is probable that any change in rainfall amount and distribution, even 


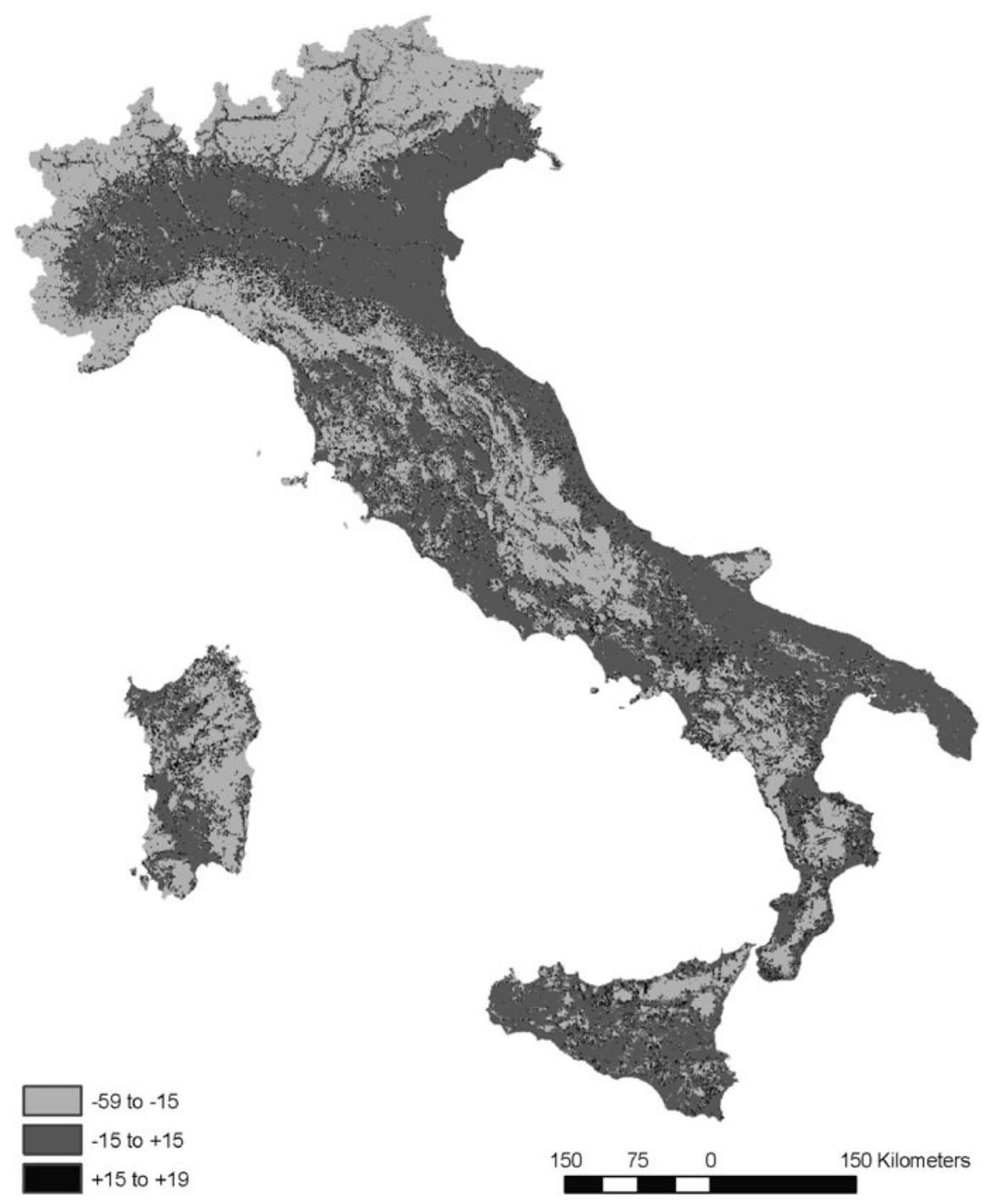

Fig. 34.12 Soil organic carbon stock variation in Italy between the first and the second studied decade

more than temperature, would affect SOC. Also, the physiographic position and lithology of the substratum are significantly related to SOC content, partly because of the interaction with climate and, most of all, land use. The class of land use in fact is by far the most important cause of SOC variation, pointing to the conservative role played by permanent meadows, and even more woodlands, in the Mediterranean environment. 


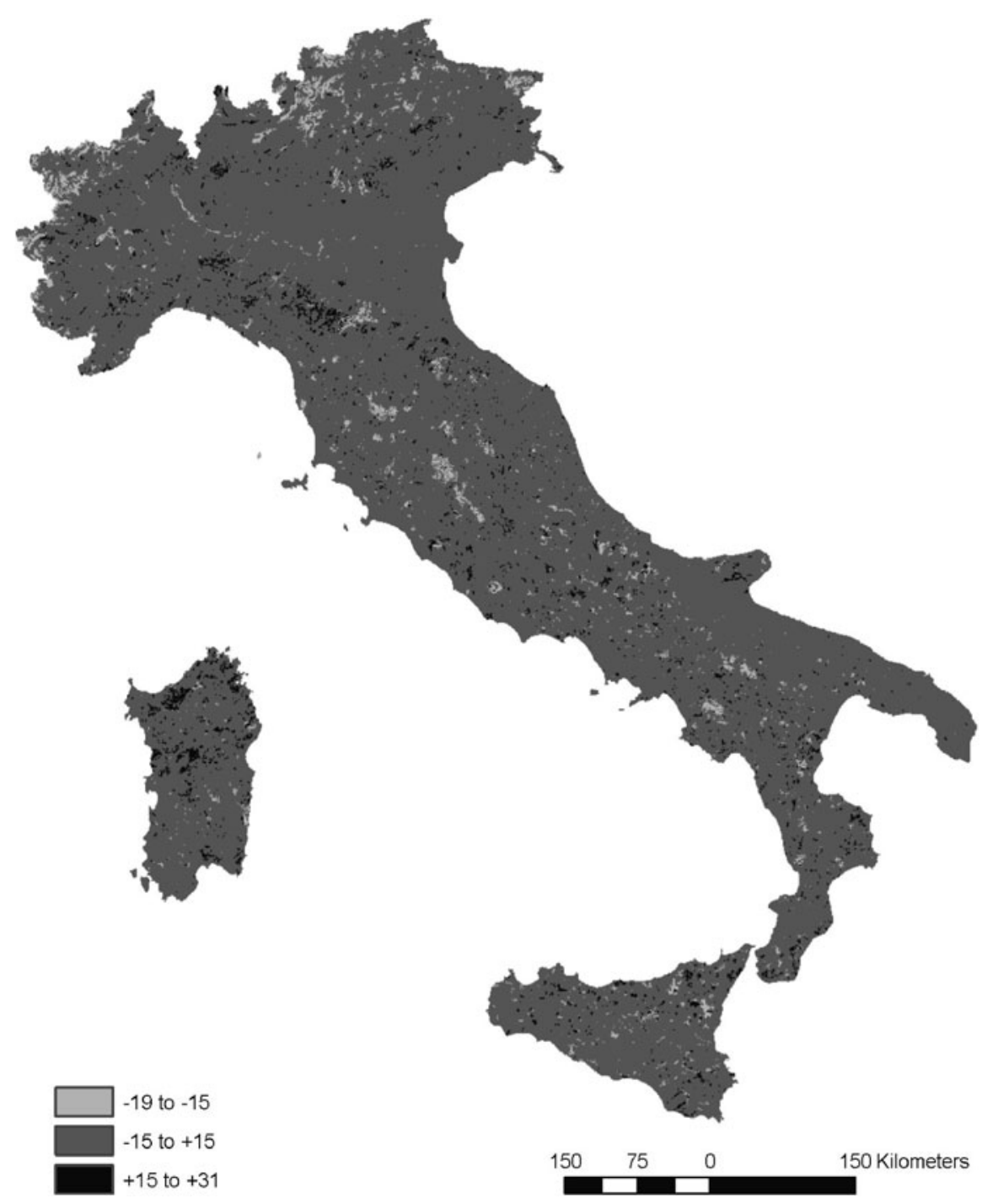

Fig. 34.13 Soil organic carbon stock variation in Italy between the second and the third studied decade

Our data highlight a significant change of the SOC content over the last three decades, which is not linear and apparently not related to major changes in main land uses. Other factors, like intensity of management, crop specialization, irrigation, adoption of conservation agriculture as a consequence of the European policies could have played an important role. In addition, we can not exclude the influence of the climate change occurred in Italy at the end of the eighties (Degobbis et al., 1995; Werner et al., 2000; Brunetti et al., 2004; Diodato and Mariani, 2007), which 

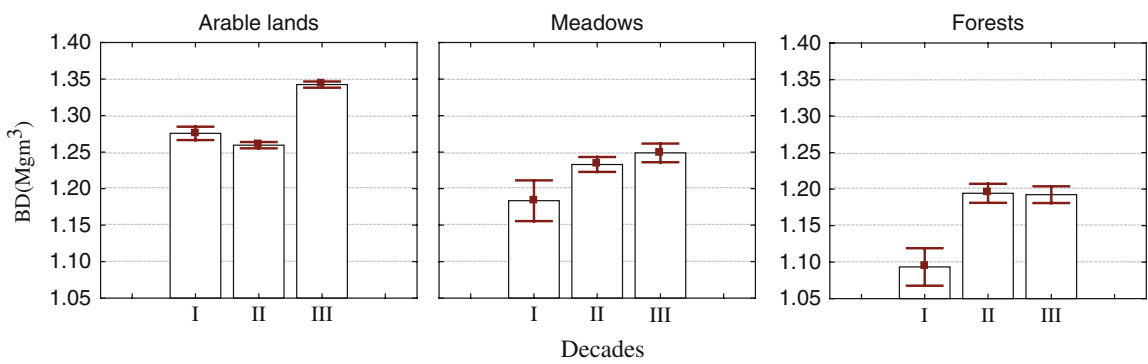

\begin{tabular}{l} 
Mean \\
\hline I Mean \pm 0.95 Conf. Interval
\end{tabular}

Fig. 34.14 Soil bulk density in the three considered decades and land uses. Differences between means are all statistically different $(P<0.01$, or $P<0.05$, between arable lands in decades I and II), except for the difference between meadows and forests in decades II and III

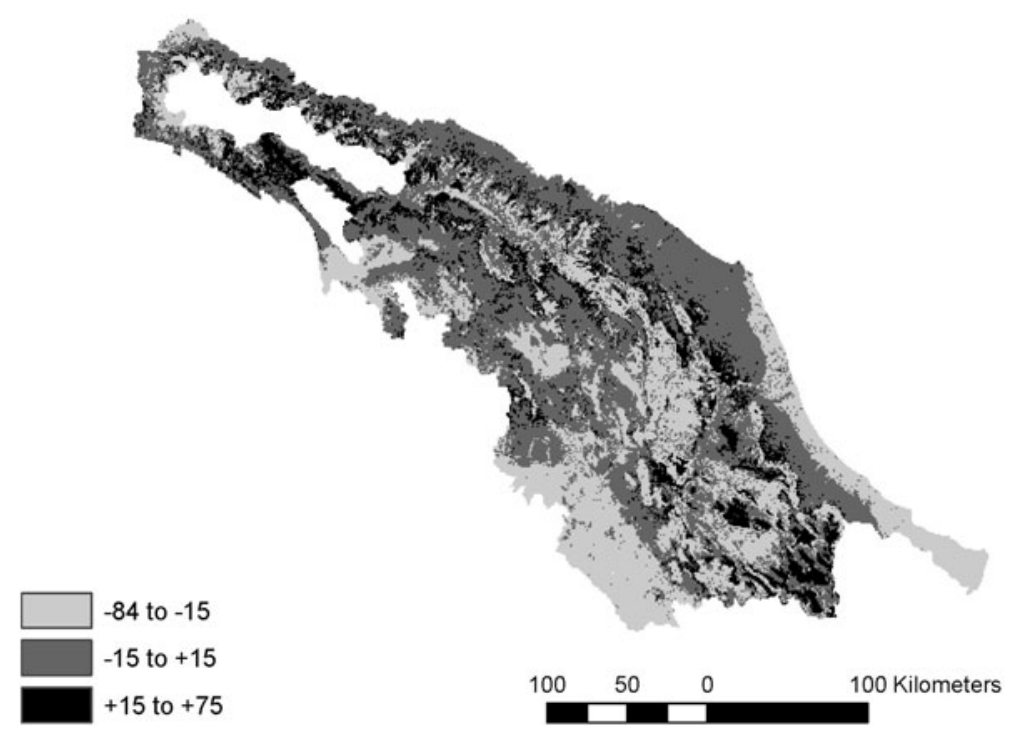

Fig. 34.15 Difference in the estimation of the soil organic carbon stock obtained with biased and unbiased data (exemplifying map)

Table 34.3 Main kind of land use of Italy, at the three reference times

\begin{tabular}{|c|c|c|c|c|c|c|}
\hline Land cover & $\begin{array}{l}1990 \\
\text { (ha) }\end{array}$ & $(\%)$ & $\begin{array}{l}2000 \\
\text { (ha) }\end{array}$ & $(\%)$ & $\begin{array}{l}2008 \\
\text { (ha) }\end{array}$ & $(\%)$ \\
\hline Arable lands & $15,484.015$ & 51.3 & $15,064.244$ & 48.6 & $14,828.800$ & 47.9 \\
\hline Forests & $12,582.853$ & 41.7 & $11,557.188$ & 37.3 & $9,371.318$ & 30.2 \\
\hline Meadows & 494.125 & 1.6 & $1,883.553$ & 6.1 & $3,158.724$ & 10.2 \\
\hline Others & $1,648.824$ & 5.5 & $2,478.408$ & 8.0 & $3,624.550$ & 11.7 \\
\hline Total & $30,209.817$ & 100.0 & $30,983.393$ & 100.0 & $30,983.393$ & 100.0 \\
\hline
\end{tabular}


increased average temperatures and augmented torrential regime of rainfall. All of these could have both directly and indirectly influenced soil erosion intensity and contributed to the observed SOC reduction.

$\mathrm{CS}$ of Italy is estimated to be at present about $2.9 \mathrm{Pg}$. The trend during the last three decades shows an important decrease in the second decade, followed by a slight increase in the third decade, mainly in arable lands. These results only partially correspond to what was found by some authors for European cultivated lands (Arrouays and Morvan, 2008), where the size of the soil organic carbon pool was estimated to be generally decreasing, while it seemed to be on increase in grasslands as well as in forests.

The observed average increase of soil bulk density of Italian soils during the last decade in arable lands, or in the nineties in permanents grasslands and forests, seems

Table 34.4 T-student test analysis for the independence of data coming from different survey sets, considered separately by soil region, decade and land use. Dashed rows indicate biased datasets

\begin{tabular}{|c|c|c|c|c|c|c|c|c|c|c|c|c|c|}
\hline $\begin{array}{c}\text { Survey } \\
\text { set }\end{array}$ & Decade & Land use & $\begin{array}{c}\text { Soil } \\
\text { regions }\end{array}$ & $\begin{array}{c}\text { Mean } \\
1 \text { st } \\
\text { group }\end{array}$ & $\begin{array}{r}\text { Mean } \\
2 \text { nd } \\
\text { group }\end{array}$ & $\begin{array}{c}\mathrm{N} \\
1 \mathrm{st} \\
\text { group }\end{array}$ & $\begin{array}{c}\mathrm{N} \\
2 \mathrm{nd} \\
\text { group }\end{array}$ & $\begin{array}{c}\text { Std. } \\
\text { dev. } \\
1 \text { st } \\
\text { group }\end{array}$ & $\begin{array}{l}\text { Std. } \\
\text { dev. } \\
2 \mathrm{nd} \\
\text { group }\end{array}$ & t-value & $\mathrm{df}$ & \multicolumn{2}{|c|}{$\begin{array}{l}\mathrm{P}(.) \text { if } \\
<0.05)\end{array}$} \\
\hline \multirow{27}{*}{ A } & \multirow{27}{*}{2 nd } & \multirow{19}{*}{ 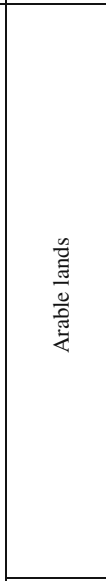 } & 16.4 & 1.569 & 2.378 & 96 & 14 & 1.190 & 1.077 & -2.402 & 108 & 0.01799 & (.) \\
\hline & & & $18.7-18.8$ & 1.404 & 1.491 & 1,782 & 56 & 1.030 & 1.786 & -0.600 & $\begin{array}{c}183 \\
6\end{array}$ & 0.54829 & \\
\hline & & & 34.2 & 1.723 & 1.326 & 93 & 36 & 0.751 & 0.926 & 2.518 & 127 & 0.01304 & (.) \\
\hline & & & $37.1-37.3$ & 1.663 & 1.387 & 56 & 18 & 1.091 & 0.752 & 0.995 & 72 & 0.32295 & \\
\hline & & & 56.1 & 1.469 & 1.616 & 236 & 7 & 1.680 & 0.663 & -0.231 & 241 & 0.81738 & \\
\hline & & & $\begin{array}{c}59.1- \\
59.2-59.7\end{array}$ & 1.332 & 1.269 & 410 & 25 & 0.813 & 0.802 & -0.375 & 433 & 0.70802 & \\
\hline & & & 60.4 & 1.187 & 1.201 & 37 & 72 & 0.423 & 1.342 & -0.062 & 107 & 0.95081 & \\
\hline & & & 60.7 & 1.115 & 1.068 & 125 & 42 & 0.561 & 0.419 & 0.499 & 165 & 0.61872 & \\
\hline & & & 61.1 & 1.106 & 1.304 & 432 & 86 & 0.591 & 0.902 & -2.570 & 516 & 0.01046 & (.) \\
\hline & & & 61.3 & 0.836 & 0.869 & 734 & 249 & 0.462 & 0.620 & 0.906 & 981 & 0.36510 & \\
\hline & & & 62.1 & 1.103 & 0.999 & 409 & 61 & 0.515 & 1.453 & 1.065 & 468 & 0.28758 & \\
\hline & & & 62.2 & 1.037 & 1.120 & 484 & 175 & 0.523 & 0.443 & -1.876 & 657 & 0.06112 & \\
\hline & & & 62.3 & 1.056 & 1.075 & 445 & 80 & 0.739 & 0.475 & -0.227 & 523 & 0.82040 & \\
\hline & & & 64.4 & 1.061 & 1.074 & 210 & 28 & 0.420 & 0.583 & -0.148 & 236 & 0.88268 & \\
\hline & & & 66.4 & 1.510 & 3.194 & 98 & 9 & 1.088 & 1.564 & -4.273 & 105 & 0.00004 & (.) \\
\hline & & & 72.2 & 1.468 & 0.887 & 133 & 12 & 0.678 & 0.397 & 2.918 & 143 & 0.00409 & (.) \\
\hline & & & 76.1 & 0.885 & 0.918 & 224 & 24 & 0.467 & 0.488 & 0.328 & 246 & 0.74337 & \\
\hline & & & 78.1 & 0.930 & 1.106 & 97 & 9 & 0.466 & 0.461 & -1.085 & 104 & 0.28025 & \\
\hline & & & 78.2 & 1.239 & 1.142 & 158 & 21 & 0.638 & 0.767 & 0.643 & 177 & 0.52082 & \\
\hline & & \multirow{8}{*}{ 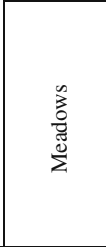 } & $16.4-16.5$ & 1.141 & 3.339 & 85 & 28 & 0.756 & 3.289 & -5.763 & 111 & 0.00000 & (.) \\
\hline & & & $59.1-59.2$ & 1.288 & 2.876 & 58 & 67 & 0.825 & 1.658 & 6.616 & 123 & 0.00000 & (.) \\
\hline & & & 59.7 & 1.668 & 2.172 & 75 & 16 & 1.072 & 1.028 & -1.721 & 89 & 0.08878 & \\
\hline & & & $60.4-60.7$ & 1.300 & 1.368 & 9 & 15 & 1.031 & 0.350 & -0.237 & 22 & 0.81511 & \\
\hline & & & $61.1-61.3$ & 0.935 & 1.105 & 181 & 34 & 0.806 & 0.674 & 1.158 & 213 & 0.24800 & \\
\hline & & & 76.1 & 0.733 & 1.054 & 12 & 21 & 0.494 & 0.336 & 2.216 & 31 & 0.03415 & (.) \\
\hline & & & $\begin{array}{c}62.1- \\
62.3\end{array}$ & 1.021 & 1.747 & 47 & 23 & 0.664 & 2.663 & -1.772 & 68 & 0.08094 & \\
\hline & & & $66.4-66.5$ & 1.275 & 3.523 & 4 & 10 & 0.695 & 2.342 & -1.847 & 12 & 0.08959 & \\
\hline \multirow{8}{*}{ B } & \multirow{2}{*}{$1 \mathrm{st}$} & Arable & \multirow{8}{*}{$\begin{array}{c}18.8- \\
34.3-78.1\end{array}$} & 1.789 & 1.145 & 149 & 20 & 1.489 & 0.411 & -1.918 & 167 & 0.05678 & \\
\hline & & Meadows & & 1.895 & 2.126 & 78 & 2 & 1.082 & 0.588 & -0.299 & 78 & 0.76556 & \\
\hline & \multirow[t]{2}{*}{$2 \mathrm{nd}$} & Arable & & 1.487 & 1.425 & 1,392 & 106 & 1.216 & 1.427 & -0.501 & $\begin{array}{c}149 \\
6\end{array}$ & 0.61618 & \\
\hline & & Meadows & & 1.818 & 1.019 & 512 & 6 & 1.304 & 0.619 & 1.497 & 516 & 0.13488 & \\
\hline & \multirow{2}{*}{$3 \mathrm{rd}$} & Arable & & 1.512 & 1.603 & 965 & 35 & 1.603 & 1.572 & -0.332 & 998 & 0.73980 & \\
\hline & & Meadows & & 1.672 & 4.089 & 165 & 10 & 1.329 & 5.619 & 4.075 & 173 & 0.00007 & (.) \\
\hline & \multirow{2}{*}{\begin{tabular}{|c|}
1 st 2nd \\
3 rd \\
\end{tabular}} & \multirow{2}{*}{ Forests } & & 2.553 & 4.934 & 125 & 22 & 2.056 & 5.438 & 3.665 & 145 & 0.00035 & (.) \\
\hline & & & & 2.509 & 1.642 & 43 & 7 & 0.926 & 1.784 & 1.985 & 48 & 0.05287 & \\
\hline $\mathrm{C}$ & $1 \mathrm{st}$ & Arable & $\begin{array}{l}16.4- \\
56.1-\end{array}$ & 1.452 & 1.229 & 242 & 76 & 1.364 & 1.161 & 1.281 & 316 & $\begin{array}{c}0.20100 \\
6\end{array}$ & \\
\hline
\end{tabular}


Table 34.4 (continued)

\begin{tabular}{|c|c|c|c|c|c|c|c|c|c|c|c|c|c|}
\hline & & Meadows & \multirow{8}{*}{$\begin{array}{c}61.1- \\
61.3- \\
64.4- \\
78.1-78.2\end{array}$} & 5.413 & 4.337 & 55 & 9 & 3.850 & 4.158 & 0.769 & 62 & $\begin{array}{c}0.44453 \\
8\end{array}$ & \\
\hline & & Forests & & 4.084 & 5.103 & 219 & 22 & 3.830 & 4.761 & -1.162 & 239 & $\begin{array}{c}0.24650 \\
8\end{array}$ & \\
\hline & \multirow{3}{*}{ 2nd } & Arable & & 1.125 & 1.045 & 237 & 398 & 0.728 & 0.776 & -1.281 & 633 & $\begin{array}{c}0.20064 \\
8\end{array}$ & \\
\hline & & Meadows & & 5.656 & 2.151 & 54 & 64 & 3.562 & 2.537 & -6.223 & 116 & $\begin{array}{c}0.00000 \\
0\end{array}$ & (.) \\
\hline & & Forests & & 2.890 & 2.273 & 70 & 130 & 2.037 & 1.651 & -2.316 & 198 & $\begin{array}{c}0.02158 \\
0\end{array}$ & (.) \\
\hline & \multirow{3}{*}{$3 \mathrm{rd}$} & Arable & & 1.465 & 1.161 & 652 & 773 & 2.281 & 0.790 & -3.463 & $\begin{array}{c}142 \\
3\end{array}$ & $\begin{array}{c}0.00054 \\
9\end{array}$ & (.) \\
\hline & & Meadows & & 3.314 & 1.917 & 176 & 195 & 2.929 & 1.532 & 5.835 & 369 & $\begin{array}{c}0.00000 \\
0\end{array}$ & (.) \\
\hline & & Forests & & 2.812 & 2.431 & 429 & 178 & 2.431 & 2.557 & 1.735 & 605 & $\begin{array}{c}0.08328 \\
1\end{array}$ & \\
\hline \multirow{7}{*}{ D } & \multirow{2}{*}{1 st 2 nd } & Arable & \multirow{7}{*}{$\begin{array}{c}35.7- \\
60.4- \\
60.7- \\
61.3- \\
64.4-78.2\end{array}$} & 1.979 & 0.926 & 53 & 75 & 3.601 & 0.449 & -2.511 & 126 & 0.01331 & (.) \\
\hline & & Forests & & 2.080 & 4.373 & 80 & 28 & 1.380 & 4.310 & 4.210 & 106 & 0.00005 & (.) \\
\hline & \multirow{2}{*}{1 st 2 nd } & Arable & & 1.318 & 0.975 & 508 & 412 & 1.350 & 0.794 & -4.560 & 918 & 0.00001 & (.) \\
\hline & & Forests & & 1.948 & 2.284 & 368 & 69 & 1.442 & 1.320 & 1.800 & 435 & 0.07260 & \\
\hline & \multirow{2}{*}{1 st $2 \mathrm{nd}$} & Arable & & 1.149 & 1.007 & 104 & 538 & 0.809 & 0.586 & -2.104 & 640 & 0.03574 & (.) \\
\hline & & Forests & & 1.935 & 2.381 & 45 & 75 & 0.988 & 2.540 & 1.125 & 118 & 0.26281 & \\
\hline & $\begin{array}{c}1 \text { st } 2 \text { nd } \\
3 \text { rd }\end{array}$ & Meadows & & 1.777 & 1.622 & 122 & 92 & 1.739 & 1.523 & -0.678 & 212 & 0.49823 & \\
\hline \multirow[b]{2}{*}{ E } & 2nd & \multirow[b]{2}{*}{ Arable } & \multirow{2}{*}{$\begin{array}{c}61.3- \\
62.1- \\
72.2-72.3\end{array}$} & 1.155 & 0.981 & 44 & 73 & 0.575 & 1.336 & -0.820 & 115 & 0.41375 & \\
\hline & $3 \mathrm{rd}$ & & & 1.068 & 0.982 & 295 & 96 & 0.551 & 0.409 & -1.407 & 389 & 0.16034 & \\
\hline
\end{tabular}

to have played a central role on CS temporal evolution. Land uses changes over the time modified the proportion of the conservative covers, thus affecting the CS. These results further stress the importance of soil management on the maintenance or increase of the national CS.

Finally, our study strongly suggest to carefully examine the bulk of data before to proceed with the elaboration of CS maps, as the values coming from different sources could be notably biased, even if samples were analysed with the same methodology. In the case of Italy, the CS estimations made using datasets that significantly deviated from the others could be as biased as the $190 \%$.

\section{References}

Alakukku, L. (1996). Persistence of soil compaction due to high axle load traffic. II. Long-term effects on the properties of fine-textured and organic soils. Soil and Tillage Research 37(4): 223-238.

Arrouays, D., Balesdent, J., Germon, J.C., Jayet, P.A., Soussana, J.F. and Stengel, P. (2002a). Mitigation of the greenhouse effect. Increasing carbon stocks in French agricultural soils? Synthesis of an assessment report by the French Instritute for Agricultural Research (INRA) on request of the French Ministry for Ecology and sustainable development. INRA, France, $36 \mathrm{pp}$.

Arrouays, D., Balesdent, J., Gerom, J.C., Jayet, P.A., Soussana, J.F. and Stengel, P. (2002b). Contribution a la lutte contre 1'effet de serre: Stocker du carbone dans les sols agricules de France? INRA, France, 332pp.

Arrouays, D., Deslais, W. and Badeau, V. (2001). The carbon content of topsoil and its geographical distribution in France. Soil Use and Management 17:7-11. 
Arrouays, D. and Morvan, X. (2008). Inventory and monitoring report. ENVASSO Work package 2 report. JRC, Cranfield, UK.

Bakken, A.K., Brandsæter, L.O., Eltun, R., Hansen, S., Mangerud, K., Pommeresch, R. and Riley, H. (2009). Effect of tractor weight, depth of ploughing and wheel placement during ploughing in an organic cereal rotation on contrasting soils. Soil and Tillage Research 103(2):433-441. doi: 10.1016/j.still.2008.12.010.

Batjes, N.H. (2008). Mapping soil carbon stocks of Central Africa using SOTER. Geoderma, Elsevier, Amsterdam 146(1-2):58-65. doi: 10.1016/j.geoderma.2008.05.006.

Bellamy, P.H. (2008). UK losses of soil carbon - due to climate change? Report on the conference Climate change - can soil make a difference? Brussels, Thursday 12 June 2008. Full presentation. Available via DIALOG. http://ec.europa.eu/environment/soil/conf_en.htm Cited 13 August 2009.

Bellamy, P.H., Loveland, P.J., Bradley, R.I., Lark, R.M. and Kirk, G.J.D. (2005). Carbon losses from all soils across England and Wales 1978-2003. Nature 437:245-248.

Bouwman, A. (2001). Global Estimates of Gaseous Emissions from Agricultural Land. FAO, Rome, p. 106.

Brunetti, M., Maugeri, M., Monti, F. and Nanni, T. (2004). Changes in daily precipitation frequency and Distribution in Italy over the last 120 years. Journal of Geophysical Research D: Atmospheres 109 (5):D05102.

Calzolari, C. and Ungaro, F. (2005). La carta della dotazione in sostanza organica della pianura Emiliano Romagnola. Il suolo 34-36(1-3):29-32. Available via DIALOG. http://www.aipsuoli.it/editoria/bollettino/n1-3a05/n1-3a05_08.htm Cited 13 August 2009.

Carre, F., Mcbratney, A.B., Mayr, T. and Montanarella, L. (2007). Digital soil assessments: Beyond DSM. Geoderma, Elsevier, Amsterdam 142(1-2):69-79. doi: 10.1016/j.geoderma.2007. 08.015.

Castrignanò, A., Costantini, E.A.C., Barbetti, R. and Sollitto, D. (2009). Accounting for extensive topographic and pedologic secondary information to improve soil mapping. Catena 77:28-38.

Cerli, C., Celi, L., Bosio, P., Motta, R. and Grassi, G. (2009). Effects of land use change on soil properties and carbon accumulation in the Ticino Pank (North Italy). In: G. Sartori (ed.), Studi Trentini di Scienze Naturali. Suoli degli ambienti alpini. volume 85, Museo tridentino doi scienze naturali, Trento, pp. 83-92.

Chai, X., Shen, C., Yuan, X. and Huang, Y. (2008). Spatial prediction of soil organic matter in the presence of different external trends with REML-EBLUP. Geoderma, Elsevier, Amsterdam 148(2):159-166.

Ciais, P., Reichstein, M., Viovy, N., Granier, A., Ogee, J. et al. (2005). Europe-wide reduction in primary productivity caused y heat and drought in 2002. Nature 437:529-533.

CORINE. (2009). COoRdination de l'INformation sur l'Environnement. http://www.eea. europa.eu/publications/COR0-landcover; http://www.clc2000.sinanet.apat.it/; http://stweb. sister.it/itaCorine/corine/progettocorine.htm Cited 13 August 2009.

Costantini, E.A.C., Barbetti, R. and L'Abate, G. (2007). Soils of Italy: Status, problems and solutions. In: P. Zdruli, G. Trisorio Liuzzi (eds.), Status of Mediterranean Soil Resources: Actions Needed to Support their Sustainable Use. Mediterranean Conference Proceedings, Tunis, Tunisia, IAM Bari (Italy), pp. 165-186.

Costantini, E.A.C., Barbetti, R. and L'Abate, G. (2009). The soil aridity index to asses the desertification risk. Advances in GeoEcology (in press).

Costantini, E.A.C., Castelli, F. and L'Abate, G. (2005). Use of the EPIC model to estimate soil moisture and temperature regimes for desertification risk in Italy. Advances in GeoEcology 251-263.

Costantini, E.A.C., Castelli, F., Lorenzoni, P. and Raimondi, S. (2002). Assessing soil moisture regimes with traditional and new methods. Soil Science Society of America Journal 66: 1889-1896.

Costantini, E.A.C. and L'Abate, G. (2009). The soil aridity index to asses the desertification risk. Advances in GeoEcology 40 CATENA VERLAG, 35447 Reiskirchen (in press). 
Costantini, E.A.C., Magini, S. and Napoli, R. (2003). A Land System database of Italy. 4th European Congress on Regional Geoscientific Cartography and Information Systems. Proceedings 1:124-126. Available via DIALOG. http://www.regione.emilia-romagna.it/ geologia/convegni/4th_congress/oral_4congr.htm\#sess01 Cited 13 August 2009.

Covington, W.W. (1981). Changes in forest floor organic matter and nutrient content following clear cutting in northern hardwoods. Ecology 62:41-48.

Dalla Valle, E. (2008). Valutazione dello stock di carbonio e delle capacità fissative delle foreste assestate e dei boschi di neoformazione nella Regione Veneto. Available via DIALOG. http://paduaresearch.cab.unipd.it/1340/ Cited 13 August 2009.

Degobbis, D., Fonda-Umani, S., Franco, P., Malej, A., Precali, R. and Smodlaka, N. (1995). Changes in the northern Adriatic ecosystem and the hypertrophic appearance of gelatinous aggregates. Science of the Total Environment 165:43-58.

Diodato, N. and Mariani, L. (2007). Testing a climate erosive forcing model in the PO River Basin. Climate Research 33(2):195-205.

European Commission. (16 April 2002). Towards a Thematic Strategy for Soil Protection. COM 179, 16 April 2002.

European Commission. (2006). Thematic Strategy for Soil Protection, COM 231.

European Commission. (2008). Final Remarks. Report on the conference Climate change - can soil make a difference? Brussels, Thursday 12 June 2008.

European Commission. (2009). European research on climate change. Catalogue of FP6 projects. Available via DIALOG. http://ec.europa.eu/research/environment/pdf/ european_research_climate_change_en.pdf. Cited 13 August 2009.

European Communities. (2003). The Lucas survey European statisticians monitor territory. Luxembourg p. 24. Available via DIALOG. http://circa.europa.eu/irc/dsis/landstat/info/data/ studiesreports.htm Cited 13 August 2009.

Finke, P., Hartwich, R., Dudal, R., Ibanez, J., Jamagne, M., King, D., Montanarella, L. and Yassoglu, N. (1998). Georeferenced soil database for Europe. Manual of Procedures. Version 1.0. ESB-JRC-SAI. European Commission, EUR 18092 EN, p. 184.

Food and Agricultural Organisation. (1974). FAO-UNESCO soil map of the word; volume 1, Legend. UNESCO, Paris.

Food and Agricultural Organisation (FAO). (1995). Global and national soils terrain digital databases (SOTER) 74 Rev.1, FAO, Rome, Italy.

Food and Agricultural Organisation (FAO). (1998). World reference base for soil resources. World Soil Resources Reports, 84. Rome, Italy, p. 88.

Franzluebbers, A.J. (2002). Soil organic matter stratification ratio as an indicator of soil quality. Soil \& Tillage Research 66:95-106. Elsevier Science B.V.

Gardi, C. (2005). Valutazione dello stock di carbonio nel suolo di prati stabili e seminativi avvicendati. Il suolo 34-36(1-3):46-49. Available via DIALOG. http://www.aipsuoli.it/editoria/bollettino/n1-3a05/n1-3a05_14.htm Cited 13 August 2009.

Garlato, A., Obber, S., Vinci, I., Mancabelli, A., Parisi, A. and Sartori, G. (2009b). La determinazione dello stock di carbonio nei suoli del Trentino a partire dalla banca dati della carta dei suoli alla scala 1:250.000. In: G. Sartori (ed.), Studi Trentini di Scienze Naturali. Suoli degli ambienti alpini. volume 85, Museo trdentino doi scienze naturali, Trento, pp. $157-160$.

Garlato, A., Obber, S., Vinci, I., Sartori, G. and Manni, G. (2009a). Stock attuale di carbonio organico nei suoli di montagna del Veneto. In: G. Sartori (ed.), Studi Trentini di Scienze Naturali. Suoli degli ambienti alpini. volume 85, Museo tridentino doi scienze naturali, Trento, pp. 69-82.

Geissen, V., Sánchez-Hernández, R., Kampichler, C., Ramos-Reyesa, R., Sepulveda-Lozada, A., Ochoa-Goana, S., de Jonga, B.H.J., Huerta-Lwangaa, E. and Hernández-Daumasa, S. (2009). Effects of land-use change on some properties of tropical soils - An example from Southeast Mexico. Geoderma, Elsevier, Amsterdam 151(3-4):87-97. doi: 10.1016/j.geoderma.2009.03.011. 
Giandon, P. (2000). Riproducibilità dei risultati delle analisi del terreno nei laboratori italiani. i risultati del confronto interlaboratorio gestito dalla società italiana dei laboratori pubblici agrochimici. ARPAV Centro Agroambientale, Italy.

Gomez, C., Viscarra Rossel, R.A. and McBratney, A.B. (2008). Soil organic carbon prediction by hyperspectral remote sensing and field vis-NIR spectroscopy: An Australian case study. Geoderma, Elsevier, Amsterdam 146(3-4):403-411. doi: 10.1016/j.geoderma.2008.06.011.

Grimm, R., Behrens, T., Märker, M. and Elsenbeer, H. (2008). Soil organic carbon concentrations and stocks on Barro Colorado Island - Digital soil mapping using Random Forests analysis. Geoderma, Elsevier, Amsterdam 146(1-2):102-113. doi: 10.1016/j.geoderma.2008.05.008.

Grunwald, S. (2009). Multi-criteria characterization of recent digital soil mapping and modeling approaches. Geoderma, Elsevier, Amsterdam 152(3-4):195-207. doi: 10.1016/j.geoderma.2009.06.003.

Guermandi, M. (2005). Protocollo di Kyoto. I suoli agricoli come "serbatoi" di anidride carbonica in Emilia-Romagna. ARPA Rivista N. 5 Settembre-Ottobre 2005.

Hirmas, D.R., Amrhein, C. and Graham, R.C. (in press). Spatial and process-based modeling of soil inorganic carbon storage in an arid piedmont. Geoderma, Elsevier, Amsterdam. doi: 10.1016/j.geoderma.2009.05.005.

Horn, R., Domzzal, H., Slowinska-Jurkiewicz, A. and van Ouwerkerk, C. (1995). The structure of the cultivated horizon of soil compacted by the wheels of agricultural tractors. Soil Compaction and the Environment. Soil and Tillage Research 35(1-2):23-36. doi: 10.1016/0167-1987(95)00479-C.

Hoyos, N.T. and Comerford, N.B. (2005). Land use and landscape effects on aggregate stability and total carbon of Andisols from the Colombian Andes. Geoderma, Elsevier, Amsterdam 129 (3-4):268-278.

Huang, X., Senthilkumara, S., Kravchenko, A., Thelena, K. and Qib, J. (2007). Total carbon mapping in glacial till soils using near-infrared spectroscopy, Landsat imagery and topographical information. Geoderma, Elsevier, Amsterdam 141(1-2):34-42. doi: 10.1016/j.geoderma.2007.04.023.

Institute Francais de l'environnement (IFEN). (2007). Le stock de carbone dans les sols agricoles diminue, 121. www.ifen.fr Cited 13 August 2009.

Intergovernamental Panel on Climate Change (IPCC). (2001a). Climate Change 2001: The Scientific Basis. Contribution of Working Group I to the Third Assessment Report of the Intergovernmental Panel on Climate Change [J.T. Houghton, Y. Ding, D.J. Griggs, M. Noguer, P.J. van der Linden, X. Dai, K. Maskell and C.A. Johnson (eds.)]. Cambridge University Press, Cambridge, p. 881.

Intergovernamental Panel on Climate Change (IPCC). (2001b). Climate Change 2001: Mitigation: Contribution of Working Group III to the Third Assessment Report of the Intergovernmental Panel on Climate Change [B. Metz, O. Davidson, R. Swart and J. Pan (eds.)], Cambridge University Press, p. 752.

Intergovernmental Panel on Climate Change (IPCC). (2003). Good Practice Guidance for Land Use, Land Use Change and Forestry [J. Penman, M. Gytarsky, T. Hiraishi, T. Krug, D. Kruger, R. Pipatti, L. Buendia, K. Miwa, T. Ngara, K. Tanabe and F. Wagner (eds.)], IPCC/OECD/IEA/IGES, Hayama, Japan.

Intergovernmental Panel on Climate Change (IPCC). (2007). Climate change 2007: Mitigation of Climate Change. Contribution of Working group III to the Fourth Assessment Report of the Intergovernmental Panel on Climate Change [B. Metz, O.R. Davidson, P.R. Bosch, R. Dave and L.A. Meyer (eds.)], Cambridge University Press, Cambridge, UK and New York, USA.

Jenny, H. (1941). Factors of Soil Formation - A System of Quantitative Pedology. McGraw-Hill, New York, USA, p. 281.

Jones, R.J.A., Hiederer, R., Rusco, E. and Montanarella, L. (2005). Estimating organic carbon in the soils of Europe for policy support. European Journal of Soil Science 56:655-671.

Kätterer, T., Andrén, O. and Person, J. (2004). The impact of altered management on long-term agricultural soil carbon stocks - a Swedish case study. Nutrient Cycling in Agroecosystems 70:179-187. 
Kirk, G.J.D. and Bellamy, P.H. (2008). On the reasons for carbon losses from soils across England and Wales 1978-2003. Global Change Biology (in review).

Lal, R. (2008). The role of soil organic matter in the global carbon cycle. Report on the conference Climate change - can soil make a difference? Brussels, Thursday 12 June 2008. Full presentation. Available via DIALOG. http://ec.europa.eu/environment/soil/conf_en.htm. Cited 13 August 2009.

L'Abate, G. and Costantini, E.A.C. (2004). GIS Pedoclimatico d'Italia. Progetto PANDA. Istituto Sperimentale Studio e Difesa del Suolo, Centro Nazionale Cartografia Pedologica, Firenze, Italia. CD-Rom.

Lal, R., Kimble, J.M., Eswaran, H. and Stewart, B.A. (2008). Global Climate Change and Pedogenetic Carbonates. Lewis Publishers, Washington, DC. Available via DIALOG. http://ec.europa.eu/environment/soil/conf_en.htm. Cited 13 August 2009.

Lal, R., Kimble, J.M., Follet, R.F. and Stewart, B.A. (2001). Assessment Methods for Soil Carbon. Advances in Soil Science. Lewis Publishers, Washington, DC, p. 676. Available via DIALOG. http://books.google.it/books?id=kgiYYADtQx0C. Cited 13 August 2009.

Luo, Y. and Zhou, Z. (2006). Soil Respiration and the Environment. Academic/Elsevier, San Diego, p. 328.

Marland, G., West, T.O., Schlamadinger, B. and Canella, L. (2003). Managing soil organic carbon in agriculture: The net effect on greenhouse gas emissions. Tellus 55B:613-621.

McBratney, A.B., Mendonca Santos, M.L. and Minasny, B. (2003). On digital soil mapping. Geoderma, Elsevier, Amsterdam 117:3-52.

Meersmans, J., De Ridder, F., Canters, F., De Baets, S. and Van Molle, M. (2008). A multiple regression approach to assess the spatial distribution of Soil Organic Carbon (SOC) at the regional scale (Flanders, Belgium). Geoderma, Elsevier, Amsterdam 143(1-2):1-13. doi: 10.1016/j.geoderma.2007.08.025.

Ministero delle Politiche Agricole Alimentari e Forestali (MIPAAF). (1992). Decreto Ministeriale 11 maggio 1992 Approvazione dei Metodi ufficiali di analisi chimica del suolo. In: Suppl. ordinario alla Gazz. Uff., 25 maggio 1992, n. 121.

Morari, F., Lugato, E., Berti, A. and Giardini, L. (March 2006). Long-term effects of recommended management practices on soil carbon changes and sequestration in north-eastern Italy. Soil Use and Management 22:71-81. doi: 10.1111/j.1475-2743.2005.00006.

Neff, J.C., Townsend, A.R., Gleixner, G., Lehman, S.J., Turnbull, J. and Bowman, W.D. (2002). Variable effects of nitrogen additions on the stability and turnover of soil carbon Nature 419:915-917.

Nyssen, J., Temesgen, H., Lemenihd, M., Zenebe, A., Haregeweyn, N. and Haile, M. (2008). Spatial and temporal variation of soil organic carbon stocks in a lake retreat area of the Ethiopian Rift Valley. Geoderma, Elsevier, Amsterdam 146(1-2):261-268. doi: 10.1016/j.geoderma.2008.06.007.

Ogle, S.M., Breidt, F., Jay, W. and Paustian, K. (2006). Bias and variance in model results associated with spatial scaling of measurements for parameterization in regional assessments. Global Change Biology 12:516-523. doi: 10.1111/j.1365-2486.2006.01106.x.

Pellegrini, S., Vignozzi, N., Costantini, E.A.C. and L'Abate, G. (2007). A new pedotransfer function for estimating soil bulk density. In: C. Dazzi (ed.), Changing Soils in a Changing Wold: The Soils of Tomorrow. Book of Abstracts. 5th International Congress of European Society for Soil Conservation, Palermo, 25-30 June 2007. ISBN: 978-88-9572-09-2.

Petrella, F. and Piazzi, M. (2005). Il carbonio negli ecosistemi agrari e forestali del Piemonte: misure ed elaborazioni. Il suolo 34-36(1-3):33-34. Available via DIALOG. http://www.aipsuoli.it/editoria/bollettino/n1-3a05/n1-3a05_09.htm Cited 13 August 2009.

Piazzi, M. (2006). Le attività della Regione Piemonte nel settore dello studio del carbonio. Soil Indicators for the Soil Thematic Strategy Support/Indicatori e metodologie a supporto della strategia tematica per il suolo. Ispra, ITALY - 21-23 November 2006. Available via DIALOG. http://eusoils.jrc.ec.europa.eu/Events/Soil_Indicators/sessione_2/Documenti/Piemonte/piem_ carbonio.doc, http://eusoils.jrc.ec.europa.eu/Events/Soil_Indicators/sessione_4/Documenti/ Carbonio_piemonte/carbonio_t_250000.jpg 
Pilli, R., Anfodillo, T. and Dalla Valle, E. (eds.)(5-8 Giugno 2006). Stima del Carbonio in foresta: metodologie ed aspetti normativi. Pubblicazione del Corso di Cultura in Ecologia, Atti del $42^{\circ}$ corso, Università di Padova. San Vito di Cadore.

Post, W.M. and Kwon, K.C. (2000). Soil carbon sequestration and land-use change: Processes and potential. Global Change Biology 6:317-327.

Reeves, P.C. (1997). The development of pore-scale network models for the simulation of capillary pressure-saturation-interfacial area-relative permeability relationships in multi fluid porous media. PhD Thesis, Department of Civil Engineering and Operations Research, Princeton University, New Jersey, USA.

Reichstein, M., Ciais, P., Papale, D., Valentini, R., Running, S., Viovy, N., Cramer, W., Granier, A., Ogee, J., Allard, V. et al. (2006). Reduction of ecosystem productivity and respiration during the European summer 2003 climate anomaly: A joint flux tower, remote sensing and modelling analysis. Global Change Biology 12:1-18.

Righini, G., Costantini, E.A.C. and Sulli, L. (2001). La banca dati delle regioni pedologiche italiane. Bollettino della Società Italiana Scienza del Suolo 50(suppl):261-271.

Sakamoto, Y. and Akaike, H. (1978). Analysis of cross classified data by AIC. Annals of the Institute of Statistical Mathematics 30:185-197. Available via DIALOG. http://www.ism.ac.jp/editsec/aism/pdf/030_1_0185.pdf Cited 13 August 2009.

Sankey, J.B., Brown, D.J., Bernard, M.L. and Lawrence, R.L. (2008). Comparing local vs. global visible and near-infrared (VisNIR) diffuse reflectance spectroscopy (DRS) calibrations for the prediction of soil clay, organic C and inorganic C. Geoderma, Elsevier, Amsterdam 148(2):149_ 158. doi: 10.1016/j.geoderma.2008.09.019.

Schils, R., Kuikman, P., Liski, J., van Oijen, M., Smith, P., Webb, J., Alm, J., Somogyi, Z., van den Akker, J., Billett, M. et al. (2008). Review of existing information on the interrelations between soil and climate change. Climsoil, Final Report. 16 December 2008.

Schimel, D.S., House, J.I., Hibbard, K.A., Bousquet, P., Ciais, P., Peylin, P., Braswell, B.H., Apps, M.J., Baker, D., Bondeau, A. et al. (2001). Recent patterns and mechanisms of carbon exchange by terrestrial ecosystems. Nature 414:169-172.

Sequi, P. and De Nobili, M. (2000). Carbonio organico. In: Violante, P. (ed.), Metodi di analisi chimica del suolo. Collana di metodi analitici per l'agricoltura diretta da Paolo Sequi, Franco Angeli, Milano.

Simbahan, G.C., Dobermann, A., Goovaerts, P., Pinga, J. and Haddix, M.L. (2006). Fine-resolution mapping of soil organic carbon based on multivariate secondary data. Geoderma, Elsevier, Amsterdam 132(3-4):471-489. doi: 10.1016/j.geoderma.2005.07.001.

Sinanet. (2009). Rete del sistema Informativo Nazionale Ambientale. http://www.clc2000.sinanet. apat.it/. Cited 13 August 2009.

Sistema Informativo Agricolo Nazionale (SIN). (2009). http://www.sin.it. Cited 13 August 2009.

Słowińska-Jurkiewicz, A. and Domazał, H. (1991). The structure of the cultivated horizon of soil compacted by the wheels of agricultural tractors. Soil and Tillage Research 19(2-3):215-226.

Smith, P. (2008). The role of agricultural practices in keeping or increasing soil organic matter. Report on the conference Climate change - can soil make a difference? Brussels, Thursday 12 June 2008. Full presentation. Available via DIALOG. http://ec.europa.eu/environment/soil/ conf_en.htm. Cited 13 August 2009.

Smith, P., Martino, D., Cai, Z., Gwary, D., Janzen, H.H., Kumar, P., McCarl, B.A., Ogle, S.M., O'Mara, F., Rice, C. et al. (2007a). Policy and technological constraints to implementation of greenhouse gas mitigation options in agriculture. Agriculture, Ecosystems and Environment 118:6-28.

Smith, P., Martino, D., Cai, Z., Gwary, D., Janzen, H.H., Kumar, P., McCarl, B.A., Ogle, S.M., O'Mara, F., Rice, C. et al. (2007b). Agriculture. In: B. Metz, O.R. Davidson, P.R. Bosch et al. (eds.), Climate Change 2007: Mitigation. Contribution of Working group III to the Fourth Assessment Report of the Intergovernmental Panel on Climate Change. Cambridge University Press, Cambridge, UK and New York, USA.

Smith, J., Smith, P., Wattenbach, M., Gottschalk, P., Romanenkov, V.A., Shevtsova, L.K., Sirotenko, O.D., Rukhovich, D.I., Koroleva, P.V., Romanenko, I.A. and Lisovoi, N.V. (2007c). 
Projected changes in the organic carbon stocks of cropland mineral soils of European Russia and the Ukraine, 1990-2070. Global Change Biology 13:342-356.

Solaro, S. and Brenna, S. (2005). Il carbonio organico nei suoli e nelle foreste della Lombardia. Il suolo 34-36(1-3):24-28. Available via DIALOG. http://www.aip-suoli.it/ editoria/bollettino/n1-3a05/n1-3a05_07.htm Cited 13 August 2009.

Stolbovoy, V., Filippi, N., Montanarella, L., Piazzi, M., Petrella, F., Gallego, J. and Selvaradjou, S. (2006). Validation of the EU soil sampling protocol to verify the changes of organic carbon stock in mineral soil (Piemonte region, Italy), EUR 22339 EN, p. 41. Available via DIALOG. http://eusoils.jrc.ec.europa.eu/ESDB_Archive/eusoils_docs/other/EUR22339EN.pdf Cited 13 August 2009.

Stolbovoy, V., Montanarella, L., Filippi, N., Jones, A., Gallego, J. and Grassi, G. (2007b). Soil sampling protocol to certify the changes of organic carbon stock in mineral soil of the european union. Institute for Environment and Sustainability. Version 2. EUR 21576 EN/2. p. 56. Office for Official Publications of the European Communities, Luxembourg. ISBN: 978-92-79-05379-5. Available via DIALOG. http://eusoils.jrc. ec.europa.eu/ESDB_Archive/eusoils_docs/other/EUR21576_2.pdf Cited 13 August 2009.

Stolbovoy, V., Montanarella, L. and Panagos, P. (eds.) (2007a). Carbon sink enhancement in soils of Europe: Data, modelling, verification. EUR 23037 EN. European Communities, 2007. Available via DIALOG. http://eusoils.jrc.ec.europa.eu/ESDB_Archive/eusoils_docs/ other/EUR23037.pdf Cited 13 August 2009.

US Dept of Agriculture (USDA). (1992, 1983, 1972). Soil Conservation Service. Soil Survey Staff. National Soils Handbook. Washington, DC.

US Dept of Agriculture (USDA). (1999, 1975). Soil Conservation Service. Soil Survey Staff. Soil Taxonomy, USDA, National natural resources Conservation Service, Washington, DC, USA.

Van Wambeke, A. (1986). Newhall Simulation Model, a Basic Program for the IBM PC [Floppy Disk Computer File]. Dep of Agron, Cornell University, Ithaca, New York, USA.

Vasques, G.M., Grunwald, S. and Sickman, J.O. (2008). Comparison of multivariate methods for inferential modeling of soil carbon using visible/near-infrared spectra. Geoderma, Elsevier, Amsterdam 146(1-2):14-25. doi: 10.1016/j.geoderma.2008.04.007.

Vettraino, B., Carlino, M. and Rosati, S. (2009). La legna da ardere in Italia. Logistica, organizzazione e costi operativi. Progetto RES \& RUE Dissemination. CEAR. Available via DIALOG. http://adiconsum.inforing.it/shared/documenti/doc2_56.pdf. Cited 13 August 2009.

Vitullo, M. (2006). Stime del carbonio in foresta: metodologie ed aspetti normativi. Gestione forestale sostenibile, lotta ai cambiamenti climatici e uso delle biomasse forestali: il progetto di ricerca del CISA. Progetto CISA. Porretta Terme, 7 luglio 2006. http://www.centrocisa.it/cisa2008/allegati/eventi/Vitullo_7luglio06.pdf Cited 13 August 2009.

Walkley, A. and Black, I.A. (1934). An examination of the Degtjareff method for determining organic carbon in soils: Effect of variations in digestion conditions and of inorganic soil constituents. Soil Science 63:251-263.

Werner, P.C., Gerstengarbe, F.W., Fraedrich, K. and Oesterle, K. (2000). Recent climate change in the North Atlantic/European sector. International Journal of Climatology 20(5):463-471.

West, T.O., Brandt, C.C., Wilson, B.S., Hellwinckel, C.M., Tyler, D.D., Marland, G., De La Torre Ugarte, D.G., Larson, J.A. and Nelson, G. (2008). Estimating Regional Changes in Soil Carbon with high spatial resolution. Soil Science Society of America Journal 72:285-294. doi: 10.2136/sssaj2007.0113.

West, T.O. and Marland, G. (2003). Net carbon flux from agriculture: Carbon emissions, carbon sequestration, crop yield, and land-use change. Biogeochemistry 63:73-83.

West, T.O. and Post, W.M. (2002). Soil organic carbon sequestration rates by tillage and crop rotation: A global data analysis. Soil Science Society of America Journal 66:1930-1946.

Zdruli, P., Jones, R. and Montanarella, L. (1999). Organic Matter in the Soils in Southern Europe, Expert Report prepared for DG XI.E.3 by the European Soil Bureau. 